\title{
Intermediate-Scale \\ High-Solids Anaerobic Digestion System Operational Development
}

\section{Christopher J. Rivard, Ph.D. Senior Scientist}

\section{Anaerobic Digestion Innovative Technologies Group National Renewable Energy Laboratory}

\section{DISCLAIMER}

\begin{abstract}
This report was prepared as an account of work sponsored by an agency of the United States Government. Neither the United States Government nor any agency thereof, nor any of their employees, makes any warranty, express or implied, or assumes any legal liability or responsibility for the accuracy, completeness, or usefulness of any information, apparatus, product, or process disclosed, or represents that its use would not infringe privately owned rights. Reference herein to any specific commercial product, process, or service by trade name, trademark, manufacturer, or otherwise does not necessarily constitute or imply its endorsement, recommendation, or favoring by the United States Government or any agency thereof. The views and opinions. of authors expressed herein do not necessarily state or reflect those of the United States Government or any agency thereof.
\end{abstract}

\section{February 1995}




\section{DISCLAIMER}

Portions of this document may be illegible in electronic image products. Images are produced from the best available original document. 


\subsection{Introduction}

Anaerobic bioconversion of solid organic wastes represents a disposal option in which two useful products may be produced, including a medium Btu fuel gas (biogas) and a compost-quality organic residue. The application of high-solids technology may offer several advantages over conventional lowsolids digester technology. Operation of the anaerobic digestion process at high solids reduces the level of process water and thereby the size and capital costs for the digester system. In addition, by virtue of the lack of available water, the microbial catalysts are more productive in feedstock polymer hydrolysis. The National Renewable Energy Laboratory (NREL) has developed a unique digester system capable of uniformly mixing high-solids materials at low cost. Information gained from 7 years of faboratory-scale digester research was used to develop the intermediate-scale digester system. This system represents a 50fold scale-up of the original digester system and includes continuous feed addition and computer monitoring and control.

During the first 1.5 years of operation, a variety of modifications and improvements were instituted to increase the safety, reliability, and performance of the system. Those improvements - which may be critical in further scale-up efforts using the NREL high-solids digester design - are detailed in this report.

\subsection{B ackground}

Research to improve the knowledge base on high solids anaerobic bioconversion systems has been a major element of the Applied Biological Sciences Branch at NREL for the past 9 years (since FY 1986). Most of this research has focused on enhancing process stability and improving process economics over conventional sewage treatment technology (i.e., the continuously stirred tank reactor, or CSTR). To this end, research was funded by the U.S. Department of Energy (DOE) Anaerobic Digestion Program, the Westem Regional Biomass Energy Program (WAPA), the DOE Energy from Municipat Waste Program, and the DOE Municipal Solid Waste Management Program. Several years of laboratory-scale research resulted in the development of a viable high solids, internally mixed, anaerobic digester system (see Keferences 1-10). Originally, this system was designed simply to study the high-solids process, and was patterned after a mixer used in the mining industry to mix ores. Following highly successful fementation studies with dRDF (densified 
refuse-derived fuel from Thief River Falls, MN) and western-area agricultural residues, the reactor design began to receive attention for possible scale-up efforts. Preliminary cost analysis from the RefCoM project (Pompano Beach, FL) as summarized by Isaacson and Benson, showed that the anaerobic digester capital costs account for $25 \%$ to $50 \%$ of the system (see Appendix 1), depending on the system configuration (i.e., gas processing option, material recovery facility (MRF) complexity, and residue processing option). Early cost analysis for the effects of high-solids operation on a full-scale system was performed using a computer model developed through Gas Research Institute (GRI) funding. The model identified a 70\% reduction in the cost of product gas over the conventional CSTR system (see Appendix 2, Legrand 1990).

Process enhancements included reduced reactor volume, reduced operating costs in the form of heating and mixing, reduced operational problems associated with foam/scum formation, and reduced or eliminated costs for effluent dewatering. With an established economic advantage and substantial fermentation experience with a variety of feedstocks, two efforts were pursued: (1) scale-up of the NREL high-solids digester design and (2) additional laboratory investigations regarding the microbial/enzymatic mechanisms responsible for conversion at high solids conditions. Within the confines of digester scale-up activities, a plan for the development of an intermediate-scale high-solids anaerobic digester system for operation at NREL was established. Additionally, much of the high-solids anaerobic digestion work focused on supporting the development of a waste treatment option for American Samoa to convert two of the island's wastes (municipal solid waste [MSW] and tuna sludge) to useful products. The success encountered in preliminary studies with these combined wastes led to ongoing efforts that focused on the rapid scale-up of the technology to address the waste problems in American Samoa.

\subsection{Intermediate-Scale System Development}

A plan for procurement and installation of an intermediate-scale high- . solids anaerobic digestion system was prepared that called for system installation to begin in December 1992. The digester system was fabricated by INTERPRO, Inc., of Golden, Colorado, through a team design approach that included INTERPRO engineers, NREL researchers, and NREL and DOE project managers. The installation of the system was held up because of delays in the shipment of equipment, a fabrication change to an internal bearing system, and 
the requirement for an extensive readiness review process (see Appendix 3). Additionally, the safe operating plan (SOP) for the system underwent extensive review in light of the quantities of flammable gas produced by the system (see Appendix 4 for the SOP document). The system was inoculated in April 1993 and experimentation began in June of 1993. The system reached the target 500L sludge volume (50\% fill) in August 1993. A variety of factors conspired to delay operation of the system at the maximum organic loading rate, including repetitive internal bearing change-outs, equipment modifications, and feedstock changes. The effect of these factors on both the operational progress of the digester system and fermentation performance is described below.

\subsection{Operational Progress}

Various changes to the original intermediate-scale digester system design were instituted to improve operation, data collection, and system control. These changes include:

4.1 Tuna Sludge Variations. Analysis of tuna sludge obtained from Pan Pacific Fisheries through conventional dissolved air floatation (DAF) in 1991 indicated that the alum/cationic polymer used to flocculate the organics resulted in an $8 \%-14 \%$ total solids sludge (consistent with that reported for the canneries in American Samoa). In addition, the $\mathrm{pH}$ of the tuna sludge was approximately $6.2-6.5$ and did not need adjustment prior to addition to the digester.

In 1992, we subcontracted with Hytech Centrifuges, Inc. (Houston, TX) to demonstrate the effectiveness of further dewatering the tuna sludge using conventional centrifugation. Using a pilot-scale, Viscotherm Rotodiff centrifuge with hydraulic back drive (scrolling), we were able to achieve an increase in tuna sludge solids to $30-35 \%$. Unfortunately, a large portion of the oil and grease was lost in the centrate indictating that centrifugation was ineffective in capturing all of the organics contained in the DAF tuna sludge.

Recently, in an effort to obtain a higher solids tuna sludge to reduce disposal costs, the canneries adopted a dual polymer system (i.e., cationic and anionic polyacrylamide). The dual polymer system performs better at low $\mathrm{pH}$, and therefore, addition of a mineral acid is customary. Using the dual polymer system, Pan Pacific has increased the total solids of the tuna 
sludge that they produce by almost $100 \%$ (total solids range from $21 \%$ $25 \%$ ). In this way, Pan Pacific reduces the transportation costs for the tuna sludge by $50 \%$. A higher solids tuna sludge is also beneficial to the high-solids anaerobic digestion process in that a higher ratio of tuna sludge to MSW may be combined for fermentation without adding significant amounts of process water to the digester. However, this higher solids tuna sludge is not without problems, and the average $\mathrm{pH}$ of the dual polymer sludge is $5.2-5.4$. In the high-solids digester which operates with a sludge $\mathrm{pH}$ range of $7.6-8.2$, this may not be a problem. However, because we are using the tuna sludge feedstock also in conventional low-solids digesters (as control systems for comparison), and these systems operate in a sludge $\mathrm{pH}$ range of $7.2-7.4$, we have opted to adjust the $\mathrm{pH}$ of the tuna sludge to 6.5 with commercial lime (Snowflake Brand, hydrated). At laboratory-scale, a commercial lime powder is added to the tuna sludge in a 5-gallon bucket and mixed with a paint stirrer.

4.2 Combined Feedstock Premixer. As the organic loading rate to the intermediate-scale digester system increased, larger quantities of feedstock materials required mixing to a uniform density prior to loading to the feed hopper. Mixing the wet tuna sludge and dry MSW by hand is difficult even at small scale. To provide for larger scale mixing of feedstock materials, a Hobart model A-200FT equipped with a bread dough hook agitator was installed. This system worked remarkably well, although a scale-up of the 20-quart model to a 80 - 120-quart unit would have more closely approximated the capacity needed to mix feedstock materials at the upper range of organic loading rates for the intermediate-scale digester. At pilot scale, a ribbon blender may be used to accomplish feedstock premixing. During size reduction of the MSW by knife milling, a smaller rejection screen was used by mistake. This resulted in a milled MSW product with a high dust potential. Therefore, a shroud was fabricated for the feedstock mixer to reduce dust contamination during the initial stage of mixing.

4.3 Feed Introduction. While a variety of feed addition systems may be applied to either liquid or dry solid feedstocks, accurate, consistent feeding of a moist solid feedstock is difficult. In addition, depending on the "quality" of sorting, the MSW feedstock may contain abrasive 
materials which quickly destroy many valve-seating surfaces, thus compromising system integrity. Either a screw feeder or a piston pump can be used to feed the premixed tuna sludge and MSW. Although a piston pump feed system also maintains system pressure, a screw feeder requires a lock hopper system. The intermediate-scale digester was designed with a 3-inch pinch valve to isolate the feed addition system during daily batch loading of feedstock to the hopper. Once the pinch valve is opened, the sealed feed hopper system maintains digester gas integrity. Periodic testing of the feed hopper lid gaskets is necessary to identify any leakage of product gas.

Since the digester system is initiated at nominal organic loading rates of 4 grams $V S / L \cdot d$ and may ultimately operate at $20-25$ grams $V S / L \cdot d$, a range of screws with increasing capacity are required.

4.4 Feed Hopper. The original feed hopper specified for the Acrison screw feeder was sufficient to load only 1 day of feedstock at a time. A new hopper was fabricated of stainless steel by INTERPRO, Inc. of Golden, Colorado. This feed hopper accommodates as much as 3 days of feedstock at a time (depending on the digester's organic loading rate). Feedstock introduction using the Acrison screw feeder has always performed satisfactorily, however, problems with feedstock bridging in the feed hopper often resulted in inadequate feed addition to the digester. In general, a dome-shaped void was created directly above the mixing arms of the screw feeder. This problem may be an artifact of the modest scale of the equipment (dimensions of the feed hopper) that we are employing. To avoid bridging in the feed hopper, we installed a vibrator (Syntron, FMC Corp.), which assists the gravity feed of feedstock materials to the screw feeder's mixing arms.

4.5 Equipment Support Structure. An Equipto ${ }^{\circledR}$ support structure was installed directly above the intermediate-scale reactor system warm room to support the feedstock addition system. In this way, the feedstock was maintained at ambient temperatures of $18-20^{\circ} \mathrm{C}$ while the digester was maintained at $37^{\circ} \mathrm{C}$. Maintaining the feedstock at a lower temperature reduces the level of biological spoilage prior to anaerobic digestion. In addition, the Equipto $^{8}$ structure isolated the variable weight of the feeder from the digester, which allowed the monitoring of digester sludge volume by weight (load cells) to be much more accurate. Prior to operation of the 
digester system at the upper end of the organic loading range, the Equipto $^{\otimes}$ structure was reinforced to allow for additional dead-weight load capability, and a custom-fabricated monorail crane system was added to safely transport the feedstock materials from the floor level to the feed hopper.

4.6 Digester Overpressure Protection. While sensors may be installed to measure the pressure within the digester and the control system may warn of potential overpressure conditions, emergency engineering control systems are required. This system must be directly installed on the digester and not potentially isolated by any valve system. Since conventional safety relief valves are inactivated by solids, we have selected a rupture disk to provide overpressure protection. As the rupture disk is exposed (at least on one side) to the mildly corrosive environment of the digester, the type of construction materials used is very important. In addition, a low activation pressure, in the range of $3-5 \mathrm{psi}$, is most desirable. Following a review of suppliers and materials of construction, we chose a graphite rupture disk produced by Zook, Inc., which is rated at 5 psi. (They now also offer the graphite rupture disk with a 3 psi rating.)

4.7 Hydraulic Motor System. A 5-piston Staffa (Vickers, Inc.) hydraulic motor system has been used on all laboratory-scale high-solids digester systems. These motors have performed continuously without downtime for more than 8 years. In fact, during a recent inspection of one of these motors by the manufacturer's representative, no significant wear to the motor was found. However, a lower cost roller stator hydraulic motor was chosen for use with the intermediate-scale digester system. Roller stator hydraulic motors are reported to provide smoother performance (especially at low $\mathrm{rpm}$ ) as compared to the piston motor system. In addition, the 5-piston motor at $35 \mathrm{hp}$ is substantially oversized as compared to the fraction of a horsepower that is actually required to provide mixing in the laboratory-scale digester. We equipped the intermediate-scale digester with a 4-hp roller stator motor, and determined that increased hydraulic pressure was required to maintain the 1-rpm agitation level. Discussions with the manufacturer, White Hydraulics, Inc., identified the slow operational speed of the motor system as the problem. In the past, we considered using a gear-reduction unit, which would allow the hydraulic motor to operate at greater rpm while 
maintaining a 1-rpm agitator speed. However, horsepower loss in gear reduction units is well documented and often hard to identify accurately, making calculation of horsepower demand for mixing imprecise. We recently identified one manufacturer (Von Ruden, Inc.) of a 16:1 gearreduction unit that guarantees greater than $98 \%$ efficiency for horsepower output. We recently purchased both a gear-reduction unit and a roller stator motor (required to match the gear-reduction unit) for installation on the intermediate-scale digester system. This system should allow for increased hydraulic motor speed with sufficient low-end torque to eliminate $\mathrm{rpm}$ fluctuations, while maintaining a 1-rpm agitator speed and allowing accurate mixing horsepower measurements.

4.8 Internal Bearing Assembly. During the fabrication of the digester system at INTERPRO, a decision was made to change the rear bearing assembly from external to the digester to an internal one. This change had the benefit of reducing the number of penetrations to the digester (and thus reduced the possibility of gas leakage). This change required an internal bearing support structure and significant research into materials of construction for such a bearing. Since the environment within the digester is considered to be mildly corrosive due to the presence of sulfides and a high level of moisture, a bearing made of noncorrosive materials was required. This was especially true since no efforts were made to allow for intermittent relubrication of the bearing. The most desirable material of construction for such a bearing would, of course, be stainless steel. However, a quick review of two major manufacturers, Dodge and Fafnir, revealed that, although the outer case of the bearing may be available in stainless, the actual bearing and races were always made of hardened steel with an industrial chrome plating.

During fabrication, an ordinary carbon steel bearing was installed in the digester by mistake. This bearing failed (froze up) after only 6 months of operation (with digester sludge). The bearing was replaced by a "corrosion-resistant" bearing (Fafnir's Survivor ${ }^{\circledR}$ series, see Appendix 5), which uses an industrial chrome plating for the races and ball bearing surfaces. This bearing included all stainless steel outer surfaces. This bearing was removed from the reactor system for inspection after 4 months of operation, and was found to have suffered only minor corrosion of the bearings and races. Following discussions with the technical support group at Dodge, a polymer sleeve bearing (see Appendix 6), 
which is truly corrosion resistant yet represents a "softer" bearing system than those previously evaluated, was installed in the intermediate-scale digester. This bearing was removed after 6 months of operation, and upon inspection did not appear to suffer any significant wear or deformation.

4.9 Digester Sludge Volume Monitoring. Conventional equipment for monitoring digester sludge volume, such as that used in low-solids sewage digesters, may not be applicable to high-solids systems. For example, floats may become weighted with attached solids, or their guide mechanisms may be fouled. Innovative approaches such as sonar sensors or measurement of digester weight by load cells may be more appropriate. In the development of the intermediate-scale digester, we installed a highly accurate digester weighing system, which is essentially a platform balance such as that used in the manufacturing industry (Toledo-Mettler, Inc.). In this case, the computer is instructed to subtract the empty weight of the digester and then calculate the total volume of sludge based on the sludge density. A similar system may also be applicable to the pilot-scale system.

4.10 Sludge Removal/Automation. The original plans for operation of the intermediate-scale digester focused on the use of a star or "pocket" valve for metered removal of sludge. However, it soon became evident that this type of valve was sensitive to hard, abrasive materials which may be in the sludge (missed during MSW sorting), which could destroy the sealing surfaces of the valve. Additionally, the moist nature of the sludge encouraged "sticking" within the valve pockets; this was true even for a sanitary finish on the stainless steel. Therefore, an alternative valve was used that approximates the way in which the "cow" controls the flow of processed feed materials (i.e., a pinch valve). The pinch valve is known for unobstructed flow similar to a ball valve, but is not sensitive to hard materials that may destroy sealing surfaces by virtue of the rubber material used. Although a manual 6-inch pinch valve was used initially, an air-actuated pinch valve was added more recently. It is important to note that rubber pinch valves may be specified in a variety of materials, including nitrile, butyl, and natural gum rubber. Our experience with the more expensive nitrile material was unsatisfactory in that it delaminated within the first 6 months of use. Whether this was due to its 
incompatibility with the sludge/biogas, or was the result of a manufacturer's defect, is still unknown; however the replacement natural gum rubber pinch valve has demonstrated no such problems in its year plus period of use.

To convey the released sludge from the digester when the pinch valve is opened, a slight overpressure is required. The intermediate-scale digester is operated at an overpressure of $0.25-0.5 \mathrm{psi}$, which is sufficient to allow for a slow release of sludge when the valve is opened. This slow release of sludge may in fact be beneficial in allowing time for the load cells to record the decreasing weight of the reactor (and hence reduced sludge volume), and thus allowing the PLC/computer control system to respond without an exceedingly large deadband.

The actual loss in digester system weight is accomplished using a screw conveyor system, which is weight-independent of the digester system. (In essence, the sludge "falls" from the pinch valve connected to the reactor into the screw conveyor.) The screw conveyor is activated at the same time as the pinch valve, but is controlled to remain in motion several minutes following the closure of the pinch valve to clear the screw flights and deposit the sludge into a receptacle. One problem which occurred in this system was that the screw conveyor capacity was undersized. This resulted in a saturating level of sludge in the screw conveyor each time the pinch valve opened. Although the additional timed operation of the screw conveyor cleared the screw flights, sludge was present in every cavity of the conveyor that was not in contact with the screw. This problem resulted in excessive odors. A larger capacity screw conveyor (with variable-speed motor drive) would solve this problem.

\subsection{Programmable Logic Controller/Computer System/Wonderware Software.} Although the original plans for operation of the intermediate-scale digester system identified various monitoring and controlling equipment, the system was far from automated. To more closely approximate an automated system, a GE/Funac series $20 / 30$ programmable logic controller (PLC) was installed to monitor and control a variety of digester parameters. An IBM-compatible computer system was added to allow a higher level of control, as well as to provide for data storage, downloading, and reporting. The system was installed with an advanced industrial automating software system known as Wonderware (from 
Intouch, Inc.). This software system also allows for remote monitoring and control of the digester through a DDE/modem linkup. The overview control screens for the digester system and the sludge removal subsystem are shown in Appendix 7, along with a representative daily report. This same Wonderware system is used by a group in New Zealand (Waste Solutions, Inc.) to "remotely" operate several digester systems for industrial clients. This system, together with a computer-linked, closedcircuit camera, would allow for NREL oversight of the pilot-scale system during testing at Terminal Island, California, and American Samoa. An uninterruptable power supply (UPS) is necessary to ensure up-time of the monitoring and control system (especially during the testing in American Samoa).

\subsection{Fermentation Progress}

It is important to note that while the high-solids anaerobic consortium is extremely stable and capable of organic loading rates (OLRs) two to four times that of conventional systems, the initial adaptation of these anaerobic microbes to the high-solids environment is tricky. In an earlier paper (1), we investigated several approaches to the adaptation of a low-solids consortium to high-solids levels, and found that patience is about the only method that works consistently. In other words, the microbes require an extended incubation time to adjust to the new level of solids (i.e., lack of available water). Although a substrate is necessary for continued biological activities during this period of adaptation, too much feedstock will result in organic acids accumulation, low $\mathrm{pH}$, and a "sour" digester. Our original intention was to inoculate the intermediate-scale digester with a high-solids sludge from the laboratory-scale systems. However, because of the relatively small size of the laboratory digesters and the high level of conversion that takes place, an extended period of time was required to generate even 40 gallons (150 liters) of sludge. Additionally, this sludge was in cold storage for a long period of time prior to use, which reduced its viability. To augment this inoculum, we also added dewatered sludge from the Denver Metropolitan Waste Water Treatment Plant's anaerobic digester. Because this sludge was unadapted to the high-solids environment, it was known to require a period of adaptation prior to exhibiting robust fermentation at high-solids levels. The fermentation performance data for the intermediate-scale high-solids digester system are shown in Appendix 8, along with the analysis of the tuna 
sludge and MSW feedstocks. A variety of problems delayed the ultimate operation of the digester system at the target organic loading rate of 20 grams $\mathrm{VS} / \mathrm{L} \cdot \mathrm{d}$, including several internal bearing change-outs, a change in MSW feedstock, and a junior operator error in feed introduction. However, the operation of the intermediate-scale digester system was successful and demonstrated during a 3-week period, stable conversion of the combined feedstock at the 20 grams VS/L・d OLR. Although the biological conversion of the chemical oxygen demand (COD) content of the combined feedstock was respectable at $71 \%$, we feel that continued adaptation of the consortium to this OLR would have provided conversions approaching $85 \%$. However, because of a lack of sufficient feedstock materials, the OLR was reduced to 6 grams $\mathrm{VS} / \mathrm{L} \cdot \mathrm{d}$, and the intermediate-scale digester system operation now focuses on developing sufficient acclimated sludge to "jump start" the pilot-plant system.

\subsection{Conclusions}

The scale-up of the laboratory-scale high-solids digester represents a major undertaking relative to digester engineering, performance monitoring, control, automation, and feedstock procurement and preparation. It was expected that the development of such a system would have its share of minor problems (even for the most well-planned project). This report serves to identify those potential problems and convey "lessons learned," which may be used in developing the pilot-scale digester system in a more timely fashion.

On the whole, the system has performed quite well, and research has confirmed the fermentation performance as determined previously using the laboratory-scale high-solids digester systems. 


\subsection{References}

1. Rivard, C.J., M.E. Himmel, T.B. Vinzant, W.S. Adney, C.E. Wyman, and K. Grohmann, 1989. "Development of a Novel Laboratory-Scale HighSolids Reactor for Anaerobic Digestion of Municipal Solid Wastes for the Production of Methane." Appl. Biochem. Biotech. 20/21: 461-478.

2. Rivard, C.J., M.E. Himmel, T.B. Vinzant, W.S. Adney, C.E. Wyman, and K. Grohmann, 1990. "Anaerobic Digestion of Processed Municipal Solid Waste Using a Novel High-Solids Reactor: Maximum Solids Levels and Mixing Requirements." Biotech. Lett. 12: 235-240.

3. Vinzant, T.B., W.S. Adney, K. Grohmann, and C.J. Rivard, 1990. "Aerobic and Anaerobic Digestion of Processed Municipal Solid Waste: Effects of Retention Time on Cellulose Degradation." Appl. Biochem. B iotech. 24/25: 765-771.

4. Rivard, C.J., and N.J. Nagle, 1992. "Biological Disposal of Tuna Processing Wastes Using a Novel Anaerobic Composting System." In Proceedings of the 1992 Food Industry Environmental Conference, 119127.

5. Rivard, C.J., 1992. "Comparison of High-Solids Anaerobic Fermentation of Selected Biomass Feedstocks with Processed Municipal Solid Waste (RDF-MSW) for the Production of Methane." In Proceedings of Energy from Biomass and Wastes XVI.

6. Rivard, C.J., 1993. "Anaerobic Bioconversion of Municipal Solid Wastes Using a Novel High-Solids Design: Maximum Organic Loading Rate and Comparison with Low-Solids Reactor Systems." Appl. Biochem. Biotech. 39/40: 107-117.

7. Rivard, C.J., N.J. Nagle, W.S. Adney, and M.E. Himmel, 1993.

"Anaerobic Bioconversion of Municipal Solid Wastes: Effects of Total Solids Levels on Microbial Numbers and Hydrolytic Enzyme Activities." Appl. Biochem. Biotech. 39/40: 71-82. 
8. Rivard, C.J., N.J. Nagle, R.A. Nieves, A. Shahbazi, and M.E. Himmel, 1994. "Anaerobic Digestion of Municipal Solid Waste: Enhanced Cellulolytic Capacity through High-Solids Operation Compared to Conventional Low-Solids Systems." ACS Books, Series 566, pp. 438-451.

9. Rivard, C.J., J.B. Rodriguez, N.J. Nagle, J.R. Self, B.D. Kay, P.N. Soltanpour, and R.A. Nieves, 1995. "Anaerobic Digestion of Municipal Solid Waste: Utility of Process Residues as a Soil Amendment." Appl. $B$ iochem. Biotech. (in press).

10. Rivard, C.J., B.D. Kay, D.H. Kerbaugh, N.J. Nagle, and M.E. Himmel, 1995. "Horsepower Requirements for High-Solids Anaerobic Digestion." Appl. Biochem. Biotech. (in press).

\subsection{Appendices}

Appendix 1. RefCoM Reactor Capital Cost Sheet

Appendix 2. Legrand Spread Sheet on Digester Cost Comparison

Appendix 3. Readiness Review for the Intermediate-Scale Digester System

Appendix 4. Safe Operating Plan for the Intermediate-Scale Digester System

Appendix 5. Survivor ${ }^{\circledR}$ Series Bearing Information

Appendix 6. Polymer Sleeve Bearing Information

Appendix 7. Wonderware Software Control Screens and Report.

Appendix 8. Feedstock Analysis and Intermediate-Scale Digester Fermentation Performance 
Table 3: Economic Assumptions

\begin{tabular}{ll}
\multicolumn{1}{c}{ Item } & \multicolumn{1}{c}{ Value } \\
\cline { 2 - 2 } $\begin{array}{l}\text { Feed Rate } \\
\text { Construction Date }\end{array}$ & 2000 tonnes/week \\
Startup Date & 1990 \\
Financing & 1992 \\
Bond Rate & Municipal Bonds \\
Bond Cost & $82 /$ year \\
Escalation & 407 of Capital Cost \\
& $52 /$ year \\
Gas Value & $\$ 4.00 / G J$ \\
Gas Cost & $\$ 5.00 / G J$ \\
Power Value & $\$ 0.03 /$ kWh \\
Power Cost & $\$ 0.06 / \mathrm{kWh}$ \\
Landfill Cost & Equal to Tlpping Fee \\
Aluninum Value & $\$ 500 /$ tonne \\
Plastics Value & $\$ 80 /$ onne
\end{tabular}

Table 4: Capital Costs and Tipping Fess for Vartous Options

\begin{tabular}{|c|c|c|c|c|}
\hline \multirow{2}{*}{ Capital Costs ( $I$ of total) } & \multicolumn{4}{|c|}{ Ootion* } \\
\hline & 1 & 2 & 3 & 4 \\
\hline $\begin{array}{l}\text { Capital Costs ( } I \text { of total) } \\
\text { Feed Preparation } \\
\text { Digestion } \\
\text { Gas Cleanup } \\
\text { Residue Processing }\end{array}$ & $\begin{array}{r}19 \\
25 \\
7 \\
49\end{array}$ & $\begin{array}{r}19 \\
25 \\
0 \\
56\end{array}$ & $\begin{array}{r}35 \\
48 \\
0 \\
17\end{array}$ & $\begin{array}{r}36 \\
49 \\
13 \\
2\end{array}$ \\
\hline $\begin{array}{l}\text { Total Cost }\left(\$ 10^{6}\right) \\
\text { Tipping Fee (\$/tonne) }\end{array}$ & $\begin{array}{l}49 \\
53\end{array}$ & $\begin{array}{l}49 \\
41\end{array}$ & $\begin{array}{l}26 \\
38\end{array}$ & $\begin{array}{l}25 \\
30\end{array}$ \\
\hline
\end{tabular}

* 1. Base Case, 2. Gasifier/Gas Iurbine, 3. Landfill Cover/Motor Generator and 4. Landfill Cover/SNG.

Depending upon the option selected, capital costs dfffered by a factor of 2. The choice of the back-end, fllter cake handling mode has the greatest effect on captal cost. For Cases 1 and 2, a relatively expensive thermal system is employed accounting for approximately $50 z$ of the total capital. Incineration is apparently one of the most expensive (cost intensive) ways to dispose of MSW. With Cases 3 and 4, the filter cake is used as landflll cover or compost thus requiring less capital, 2 to 177 of the total.

The capital required for feed preparation and digestfon are constant across all four options, however, due to variations in total capital, their percentages vary considerably. The gas cleanup wodule employed in Cases 1 and 4, contrfbutes only $\$ 3$ million to capital. In Cases 2 and 3 , SNG is not a product and minimal processing, thus capital, is needed for utflizing the biogas in a gas turbine or wotor generator.

The total capital costs vary from $\$ 25$ willion to $\$ 49$ willion or $\$ 63,000$ to $\$ 122,000$ capital for each tonne per day capacity. Resulting breakeven tipping fees decrease from Case 1 through Case 4. The Base Case, \#1, Is the most expensive option at $\$ 53$ per tonne. The tipping fee is high due

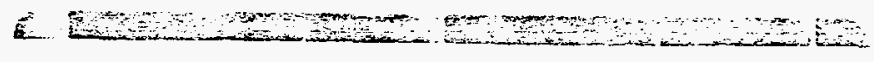

Appendix 1 . 
Table 6. Parameter Values used for Biogasification Technology Comparison (Figure 25)

\begin{tabular}{|c|c|c|c|c|}
\hline Parameter & Units & RefCOM & SOLCON & SERI HS \\
\hline Cost-Optimal $\begin{array}{r}\text { HRT } \\
\text { SRT }\end{array}$ & $\begin{array}{l}\text { days } \\
\text { days }\end{array}$ & $\begin{array}{l}23 \\
23\end{array}$ & $\begin{array}{r}25.5 \\
51\end{array}$ & $\begin{array}{l}40 \\
67\end{array}$ \\
\hline 1st Order Rate Constant & day $^{-1}$ & 0.155 & 0.155 & 0.10 \\
\hline Influent TS\% & $\%$ TS & 16.5 & 8.7 & 53.6 \\
\hline VS Loading Rate & $\begin{array}{l}\text { Ibs VS/Cu ft/day } \\
g \mathrm{VS} / \mathrm{L} / \mathrm{day}\end{array}$ & $\begin{array}{l}0.37 \\
5.92\end{array}$ & $\begin{array}{l}0.15 \\
2.40\end{array}$ & $\begin{array}{r}0.75 \\
12.00\end{array}$ \\
\hline vs Conversion \% & $\%$ & 72 & 82 & 80 \\
\hline Effiuent TS\% & $\%$ TS & 8.0 & 4.0 & 27.9 \\
\hline Methane Yield & 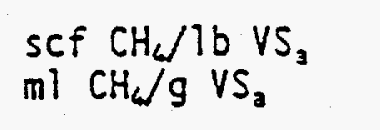 & $\begin{array}{r}5.03 \\
314\end{array}$ & $\begin{array}{r}5.72 \\
357\end{array}$ & $\begin{array}{r}5.61 \\
350\end{array}$ \\
\hline SNG Production & $\begin{array}{l}\text { lOEG } \mathrm{scf} / \text { day } \\
\text { IOE3 } \mathrm{m}^{3} / \text { day }\end{array}$ & $\begin{array}{l}2.27 \\
64.3\end{array}$ & $\begin{array}{l}2.58 \\
73.1\end{array}$ & $\begin{array}{l}2.53 \\
71.6\end{array}$ \\
\hline Active Digester Volume & $\mathrm{m}^{3} \mathrm{~m}^{3} \mathrm{Cu} \mathrm{ft}$ & $\begin{array}{r}1,302 \\
36,900\end{array}$ & $\begin{array}{r}3,148 \\
89,200\end{array}$ & $\begin{array}{r}637 \\
18,000\end{array}$ \\
\hline Total Cost & S/MMBtu gas & $\$ 15.09$ & 511.25 & 510.53 \\
\hline \multicolumn{2}{|c|}{$\begin{aligned} & \approx \text { of Cost in } \text { Preprocessing } \\
& \text { Biogasification } \\
& \text { Gas Utilization } \\
& \text { Postprocessing } \\
& \text { Landfilling }\end{aligned}$} & $\begin{array}{r}18 \% \\
37 \% \\
9 \% \\
1 \% \\
36 \%\end{array}$ & $\begin{array}{l}21 \% \\
31 \% \\
12 \% \\
12 \% \\
36 \%\end{array}$ & $\begin{array}{r}23 \% \\
25 \% \\
10 \% \\
10 \% \\
40 \%\end{array}$ \\
\hline \multicolumn{2}{|c|}{$\begin{aligned} \text { \% of Income in Tipping fees } \\
\text { Recyclables Sale } \\
\text { Gas Sale }\end{aligned}$} & $\begin{array}{l}61 \% \\
6 \% \\
33 \%\end{array}$ & $\begin{array}{r}72 \% \\
7 \% \\
21 \%\end{array}$ & $\begin{array}{l}79 \% \\
7 \% \\
14 \%\end{array}$ \\
\hline Levelized Gas Cost & S/MMBtu & $\$ 5.00$ & $\$ 2.37$ & 51.48 \\
\hline
\end{tabular}

Note: Biogas cleaned up to SNG, all residues landfilled. Biogasification tipping fee $=540 /$ ton .

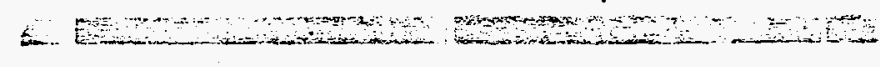

Appendix 2. 
TO:

Safety and Security Office

FROM: $\quad$ Chris Rivard

DATE:

March 29, 1993

SUBJECT:

Operation/safety review (Readiness Verification) of the intermediatescale high solids reactor system (FTLB high bay)

On March 3, a Readiness Verification meeting was held in FILB 153/131 concerning the operation and safety of the intermediate-scale high solids reactor system. This meeting was to ensure that members of the waste management program, division and branch managers, safety and security office and facilities understood the system and had an opportunity to ask questions concerning the system prior to startup. In attendance at this meeting was Phil Shepherd. Chartie Wyman, Mark Finkelstein. Nick Nagle, John Brigham, Brian Kay, Mike Andreas. Deborah Amidaneau, Jodi Donley, and Randy McConnell. Through the course of the meeting several good questions were answered and a few imporiant changes to the current operction were made. Therefore, as an outcome of this meeting several modifications to the original operation/safety procedures were made and the overall process outtined in a specific SOP.

On March 12, a secondary meeting was held in the high bay of the FIL to review the system and operation with Deand Luke, who could not be present at the origind Readiness Verification and with Randy McConnell. The outcome of this meeting was that the modifications to the system were appropriate and upon approval of the SOP the system could be staried.
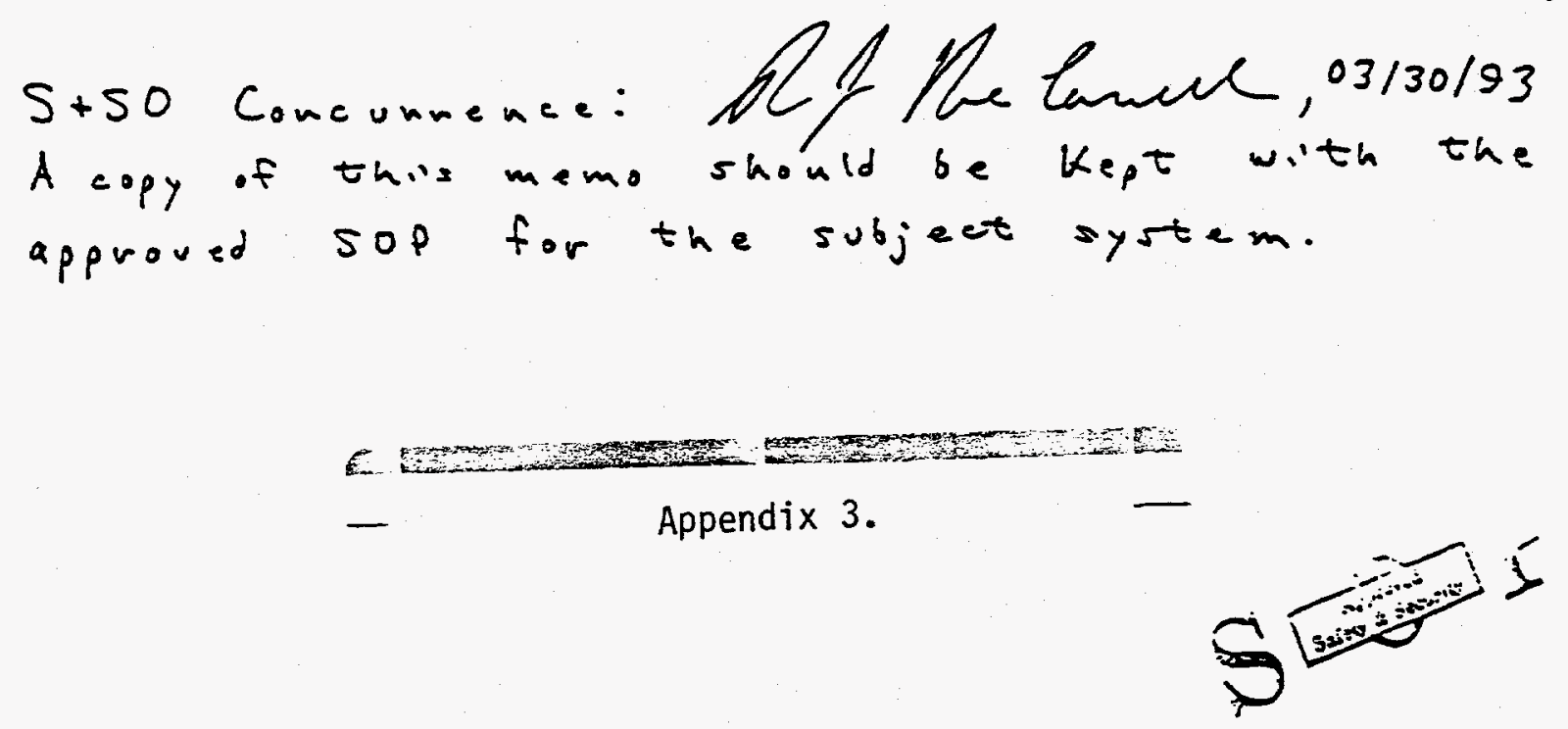


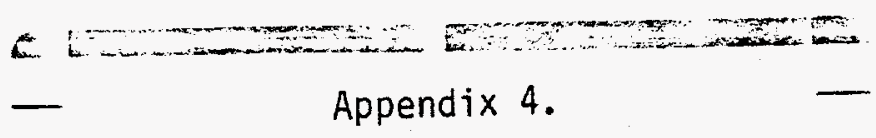

SOP \#453009303

ISSUE DATE $03 / 93$

BRANCH NUMBER 4220

\section{SAFE OPERATING PROCEDURE FOR}

Intermediate-Scale Anaerobic High Solids Reactor

AT

FTLB High Bay (Lab 131) Warm Room

The activities covered by this SOP pertain to the operation and use of the intermediate-scale ( 1000 liter) high solids anaerobic reactor system contained within the warm room of the FTLB high bay (laboratory 131). This fermentation system was designed and fabricated to study continuous, scaleup anaerobic bioconversions of a variety of feedstocks at high solids levels for the production of methane. Specifically, this SOP relates to the operation and safety aspects of this scale-up reactor in its continuous use.

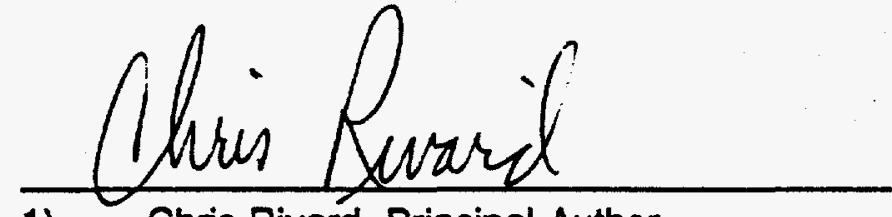

1) Chris Rivard, Principal Author
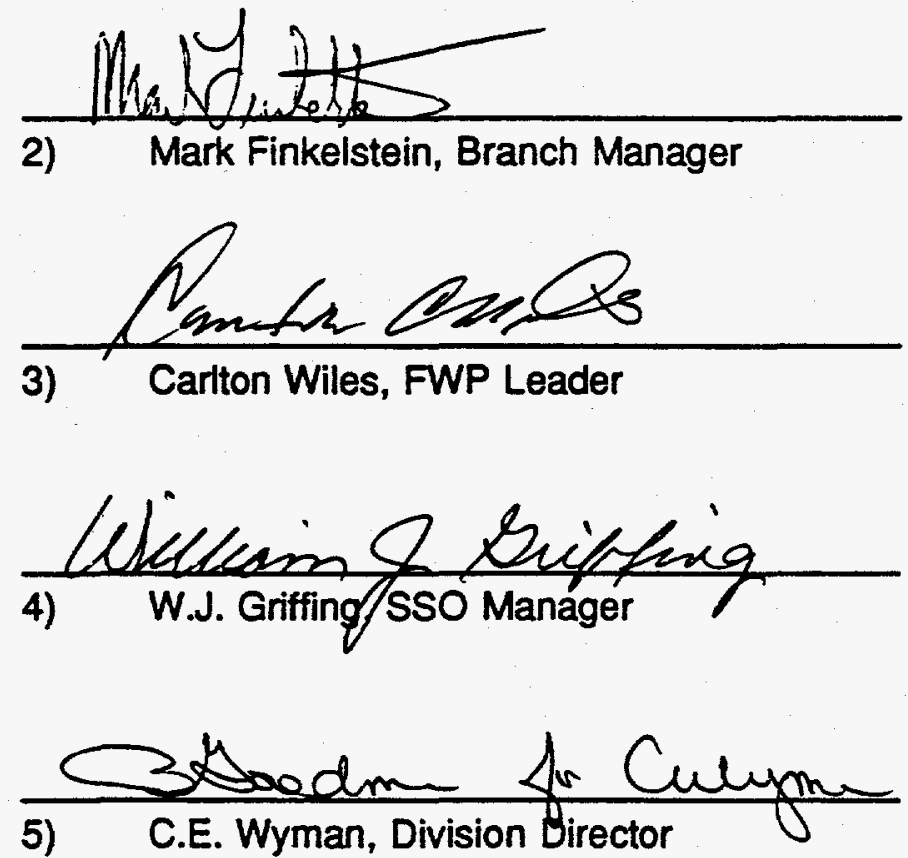
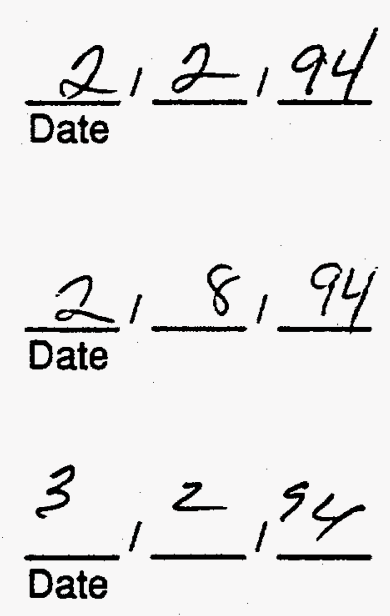

$$
\frac{3}{\text { Date }} / 22 / 94
$$

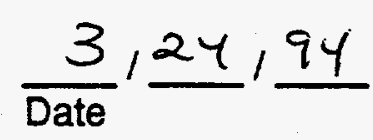

Signature numbers indicate sequence of review and approval. After all required signatures are obtained, submit a final copy of the SOP to the Safety and Security Office (SSO). 


\section{INTRODUCTION}

The concept of Anaerobic Digestion at high solids concentrations allows more favorable economics for processing of organic wastes while producing a useful fuel in the end-product, methane. The Applied Biological Sciences Branch (4220) is currently investigating the new technology of Anaerobic High Solids Digestion (AHSD) in light of energy production.

The anaerobic decomposition of organic matter, which includes biomass and municipal solid waste (MSW), is a natural biological process. The process results in the production of methane gas and non-digestible residues. These residues have often been used as fertilizers and soil enhancement substrates, and therefore do not pose a health or safety risk.

The intermediate-scale high solids reactor represents a scale-up of the original laboratory-scale high solids reactors which are covered in SOP \#19900870. The intermediate-scale system represents a 50 fold increase in reactor volume (1000 liters) over the laboratory-scale systems (20 liters). In general, the reactor is identical to the previous laboratory-scale design utilizing the horizontally mixed reactor, equipped with a feed introduction port, a gas collection port and residue removal port (see Appendix A). Mixing is achieved using a hydraulic-driven motor, and the high solids reactor is operated in a temperature-controlled environmental room at $37^{\circ} \mathrm{C}$ in the FTLB high bay.

Research focuses on confirming fermentation data developed in the laboratory-scale systems and determining scale-up sensitivities for the process. Although the duration of this research effort cannot be determined at this point, the continuous operation of the intermediate-scale reactor system is currently estimated at several years. Process feedstocks and residues are composed of simple organic materials and do not pose an exposure or health risk and can be handled with ordinary care.

This research is to be conducted only by staff members of the Applied Biological Sciences Branch.

\section{DESCRIPTION OF SAFETY \& HEALTH HAZARDS AND CONTROLS}

Possible hazards involved in the operation of the intermediate-scale high solids reactor systems include accessing the continuous feed system (acrison feeder), accessing the reactor's mixing system, and the production of a potentially flammable gas product.

In order to minimize the safety risks associated with the operation of the intermediate-scale high solids reactor system, several engineering controls have been installed. These include an electrical lockout (keyed) system for the feeder. The keyed switch is located within the warm room next to the reactor system. Additionally, two electrical disconnects for the mixing system have been installed within the room as "EPO" switches. A large red button electrically shuts down all reactors within the warm room (the intermediate-scale reactor and two laboratory-scale reactors) while a yellow buttoned switch electrically shuts down only the intermediate-scale reactor system. Problems with potentially developing excessive pressure within the reactor is eliminated through the use of a 5 psig rupture disk (Zook, Inc.) on the 3-inch feed port and a 10 psig rupture disk on the 3-inch gas removal port. The biogas produced by the fermentation process is removed from the system to a gas meter outside of the warm room and exhausted from the building using a 12-inch exhaust duct which also ventilates the warm room. In this method of disposal, the flammable biogas (60\%-70\% methane) is diluted in the exhaust duct to below $5 \%$ and therefore the gas is no longer flammable. Backup-power 
and exhaust fans serve to ensure that the exhaust system operates continuously. In the event of a catastrophic failure of the exhaust system, an alarm sounds alerting the facilities group (and guards during off-hours) to the loss in the system's operation. Should the system be down for an extended period of time ( $>2$ hours) a list of operators for the intermediate-scale high solids reactor system will be called by the responding facilities personnel. In addition to the facilities alarm system, a separate air flow sensor was installed within the exhaust duct above the warm room which will continuously monitor air flow and alarm in the event of an exhaust system failure. This system includes a variable flow indicator panel calibrated by facilities (M. Andreas) in feet per minute (FPM), an audible alarm for loss of air flow, and an amber waming beacon. Additionally, a "smooth talker" alarm modem system is installed which automatically telephones a programed list of telephone numbers with a recorded message in the event of an alarm. The installation of this system ensures redundancy in waming of a loss of exhaust and ensures that an appropriate operator will be notified.

In the event of an extended loss in exhaust system operation, the continuous flow of biogas will be manually redirected from the exhaust duct to the exterior of the building via gas tubing set aside for this potential use. This method of biogas disposal will ensure that the flammable gas is diluted and removed from the building during the time repairs are made to the house exhaust system. Following repair of the exhaust system the biogas will again be redirected to the exhaust system.

\section{DESCRIPTION OF ENVIRONMENTAL HAZARDS AND CONTROLS}

Air and Water Emissions -- The intermediate-scale high solids reactor system is an open system whereby the fermentation gases produced within the reactor are allowed to escape through a metering system into the FTLB high bay exhaust system. Therefore through dilution of this biogas, the concentration of flammable gases can never reach combustion levels $(>5 \% \mathrm{v} / \mathrm{v})$. The use of a positive ventilation system within the warm room ensures in a similar manner that any minor fermentation gas released within the room are rapidly diluted and removed from the building. Information conceming rates of biogas production and warm room ventilation capacities are provided in Appendix B.

Hazardous Waste - The organic feedstocks and process residues do not pose an environmental handling or storage problem. The feedstocks used in the process are either natural biomass forms such as wheat straw or corn stover or ordinary domestic wastes such as municipal solid waste (MSW). In the case of MSW, this material has been evaluated using the U.S. EPA protocol for evaluating the possible hazardous nature of materials through the Toxicity Characteristic Leaching Procedure (TCLP) for priority metals. Only waste materials which are not considered hazardous are utilized in research efforts. The microbial catalysts used in this process are a consortium of anaerobic microbes derived from natural sources such as landfills, animal manures and digested sewage sludge. This system does not utilized genetically modified microorganisms. Therefore, residues which are not utilized for research purposes may be disposed of either in the sanitary sewer system or the ordinary solid waste collection system (garbage).

Waste Minimization - Hazardous or regulated chemicals are not utilized in research covered by this SOP.

Decommissioning - Potentially hazardous residual contamination of equipment or facilities is not an aspect of research covered within this SOP. 
As described in section 2, various operational and engineering controls have been developed to ensure the smooth and safe continuous operation of the intermediate-scale reactor system. Unlike many experimental studies, anaerobic fermentation research requires operation of a continuous process to attain steady state rate data. In order to satisfy the need for continuous system operation, the high solids digesters must be monitored and feed added every day (including weekends). Although this requirement represents a burden on the operators, daily support of these systems ensures that process perturbations are attended to within 24 hours.

The intermediate-scale reactor system is maintained daily through the following procedure. Manual reading of product biogas production from the gas meter is recorded in the laboratory notebook. Recharging the feeder system is initiated by locking out the feeder power utilizing a keyed switch mounted within the warm room. The lockout key remains with the operator during this procedure. The feeder is isolated from the reactor system via closure of a 3-inch ball valve mounted directly above the reactor. Feed material is loaded into a suitable sized bucket and attached to the lifting system attached to the Equipto structure above the warm room. Initially, this system will be a sturdy rope with a clasp/hook. In a later modification of the Equipto structure an electric hoist attached to a boom attached to the Equipto structure will be used. The technician now climbs the ship ladder (109 inches) to the top of the Equipto structure (over the warm room). The technician draws up the rope (or actuates the electric hoist) to transfer the feed bucket to the structure. As the feeder has been electrically disconnected previously, the top of the hopper is removed, the feed added, and the top secured. The empty feed bucket is lowered from the Equipto structure using the rope (or hoist) and the technician returns to the warm room. The 3-inch ball valve on the feed port is opened and the keyed lockout switch is actuated to reestablish feed introduction to the system. The organic feedstock added to the fermentation system is converted to one of two products during the process. The biogas which is composed of $60 \%-70 \%$ methane and the remainder carbon dioxide is removed from the reactor as a result of over pressure. Pressure within the reactor is less than 1 psig as a result of the gas metering system. The biogas is transported to the gas meter using 3/8-inch O.D. braided Tygon tubing and from the gas meter using the same tubing to the exhaust duct (12-inch) located above the warm room. (This same exhaust duct also ventilates the warm room containing the high solids reactors.) The operation of the exhaust system is monitored daily by visual inspection of the air flow meter panel. Alarms waming of insufficient air flow were described in section 2 . In the event of insufficient air flow for the exhaust system, a 30 foot length of 3/8-inch braided Tygon tubing (located near the gas meter) is used to redirect the biogas to the outside of the building via the window immediately outside the south double doors of the high bay. Organic residues composied of non-biodegradable organic polymers and microbial cells is removed from the system using a 6-inch port and a pinch valve. This pinch valve is constructed of flexible heavy wall rubber and in the present design is manually operated. Residue is removed from the system once a day to a predefined total reactor weight (empty reactor weight plus $\mathbf{5 0 0}$ liters of sludge weight). The total weight of the reactor is determined by the electronic platform scale on which the reactor sits. The organic residue is removed from the warm room and stored in plastic lined drums in the cold room of the high bay (lab 131) at approximately $4^{\circ} \mathrm{C}$ until use. As described above, these residues have been previously analyzed and were determined to be non-hazardous in nature and may therefore be ultimately disposed of in the ordinary sewer or solid waste.

This system may be modified later for computer automation with inputs for reactor temperature, pressure, gas production, and system weight. The computer may then control residue removal based 
upon the modification of the pinch valve to automated operation. In this case, the residue would be removed periodically over the 24 hour period between system support. This residue would be collected in a discharge bin and would be removed daily and stored in the cold room.

If the procedures and engineering controls outlined above are adhered to, operation of the intermediate-scale high solids reactor poses no danger.

\section{PERSONNEL TRAINING}

Personnel operating the intermediate-scale high solids reactor equipment are only those that have been designated as operators and should read and observe this SOP. In addition, if the operator has any questions conceming this SOP or general operational procedures he/she should contact Chris Rivard before use. The intermediate-scale high solids reactor system is to be operated only by authorized personnel within the Applied Biological Sciences Branch.

\section{EMERGENCY INFORMATION}

In case of any unusual occurrence, the operator should first push the yellow emergency cut-off switch located on the north wall (comer), which will discontinue hydraulic flow through the directional valves. This action serves to stop the mixing device for only the intermediate-scale high solids reactor system. In the case of a general emergency, the red cut-off switch (north wall comer) should be pushed. This switch stops the mixing systems for all reactors within the warm room. Second, the operator should disconnect power to the hydraulic power plant located at the southeast comer of the high bay.

\section{AUTHORIZED PERSONNEL}

The following Applied Biological Sciences Branch personnel are authorized to use the intermediatescale high solids reactor system: Chris Rivard, Nick Nagle, Brian Kay, and David Kerbaugh.

\section{REFERENCES}

None.

\section{APPENDICES}

A.) Design sketch of the intermediate-scale high solids reactor system and associated equipment.

B.) Memo to Deana Luke dated September 2, 1992.

10. ADDENDUM 


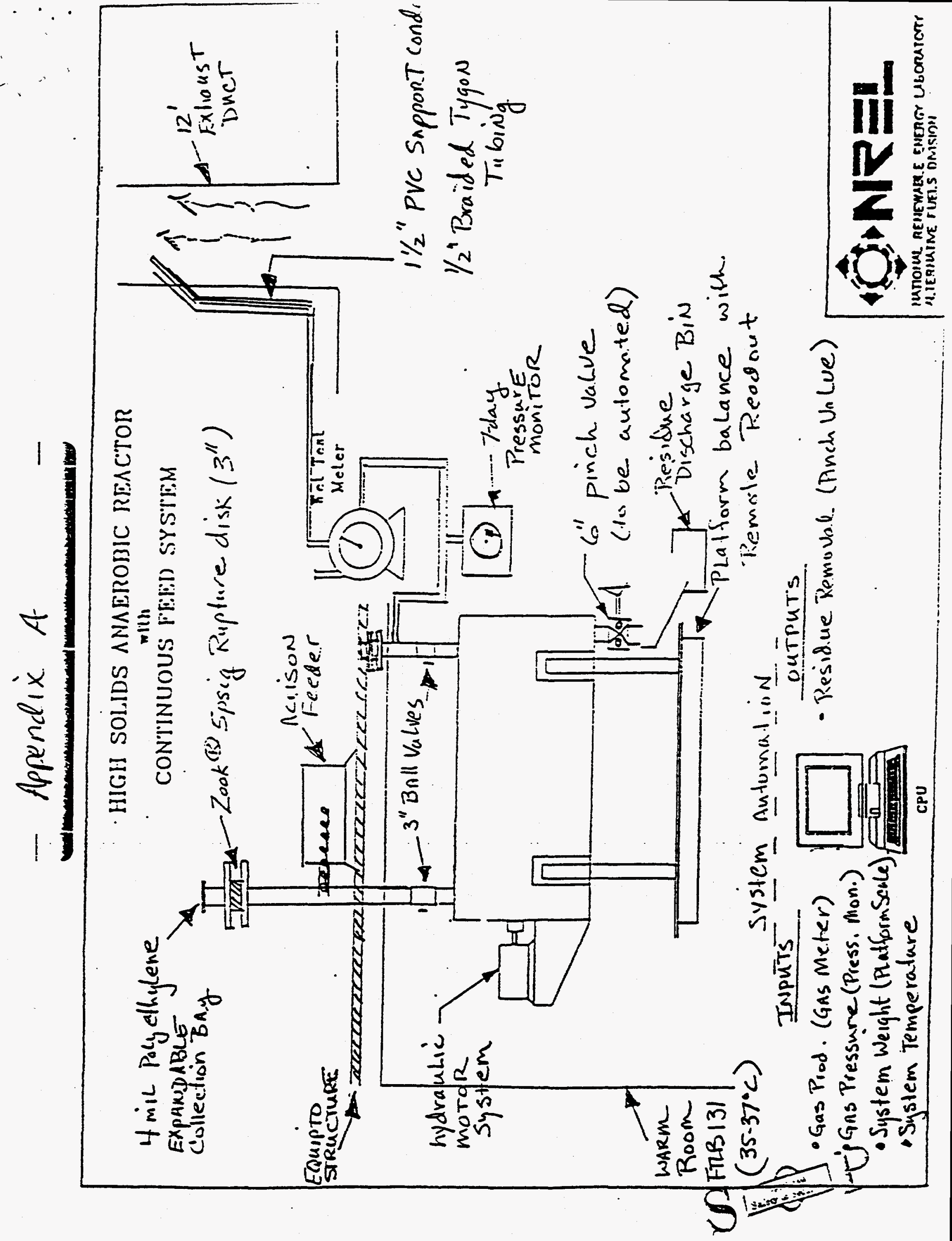


TO:

Deana Luke, sso Coordinator

FROM:

Chris Rivard, ABS Branch

DATE:

September 2, 1992

SUBJECT:

Projections for Intermediate Scale High Solids Anaerobic Digester Installation in the FLB High Bay Warm Room

The following information was prepared in order to evaluate potential $\$ S O$ issues concerning the installation of an intermediate scale high solids anaerobic digester in the warm room of the FiLB high bay. Only issues of flammable product gas production and disposal are acdressed here. Issues concerning the storage and handling of feedstock materials and the disposal of non-hazardous organic residues from this biological degrcdation process are addressed in the following SOP's; $\$ 382 \mathrm{CO} 108$, $199 \mathrm{CO} 8706$, and $\neq 152008410$.

The dcto in table I was calculated from projected equipment sizing, feedstock organic loadings, and from previous information from experiments concerning biogas production and methane composition.

Table 1 Projections for Intermediate Scale High Solids Digester Operction in the FTLB High Boy

\begin{tabular}{|c|c|c|}
\hline Parameter & Units & Estimate \\
\hline Reactor Total Volume & lifers & 1000 \\
\hline Reactor Working Volume & liters & 750 \\
\hline Operating Temperature & ${ }^{\circ} \mathrm{C}$ & $35-37$ \\
\hline Process Feed Rate (specific) & $\mathrm{g} \mathrm{VS} / \mathrm{L} \cdot \mathrm{d}$ & $10-20$ \\
\hline (total) & $\mathrm{Kg} \mathrm{VS} / \mathrm{d}$ & $7.5-15$ \\
\hline Biogas production (specific) & $\mathrm{mL} / \mathrm{gVS} \cdot \mathrm{d}$ & 590 \\
\hline (total) & L/d & $4425-8850$ \\
\hline Methane composition & $\%$ & $57-65$ \\
\hline Methane production (total) & L/d & $2522-5753$ \\
\hline
\end{tabular}


The biogas produced during the high solids fermentation is transferred from the warm room via plastic (Tygon) tubing to gas measurement equipment located immediately adjacent to the warm room in the open high bay. For the small scale high solids reactor system in which the working volume is approximately $10-18$ liters and which produce approximately $20-150$ liters of biogas per day, following measurement in wet tip gas meters the biogas is continuously diluted in the greater high bay space. This dilution reduces the methane content from $57-65 \%$ to below the level of flammability in air (5\%). However, the intermediate scale high solids digester is projected to produce substantially greater volumes of biogas and thus methane which are not appropriate for dilution in the high bay. The intermediate scale system will also utilize a conventional wet test meter for gas measurement. Therefore, following measurement in the wet test meter, the biogas will be transferred to the building exhaust system via appropriate sized tubing. Exhousting the biogas in this manner will ensure that biogas cannot collect in either the warm room or the high bay and that the methane content of the biogas is diluted to levels below flammability.

Currently, the warm room, which is used to maintain the high solids reactor systems. is actively ventilated using the building exhaust system. This positive ventilation ensures that minor biogas intrusions to the warm room atmosphere are rapidly eliminated, such as during periodic access of the recctors (i.e.. during feed introduction). Generd information as to the warm room capacity and ventilation system are detalled below in table 2.

Table 2 Information as to Air Handling Characteristics of the FTLB High Solids Warm Room

\begin{tabular}{|c|c|c|}
\hline Parameter & Units & Values \\
\hline Warm Room (dimensions) & $w \times d \times h(f)$ & $13.5 \times 7 \times 7.5$ \\
\hline (air volume) & cu ft & 709 \\
\hline (air volume) & liters & 20.079 \\
\hline Exhaust velocity* (duct) & cu ft/min & 247 \\
\hline Room air exchange rate & exchanges $/ \mathrm{hr}$ & 21 \\
\hline
\end{tabular}

Exnoust auct air velcciry cerermined on $9-2-92$ oy $\mathrm{M}$. Ancreas (focilifies).

The information as to the exhaust duct velocity was determined by the facilities branch and was tested for the worst case scenario in which all other ducts to the building exhaust system in the high bay were open and the doors to the warm room were closed. Therefore, the exhaust velocity determined represents the minimum level possible (i.e.. if warm room doors are opened or other ducts to the exhaust system are closed, the ventilation will be higher). Clearly, from this information, the operation of the intermediate scale high solids reactor does not pose a safety or security risk to laboratow personal or the FTL.

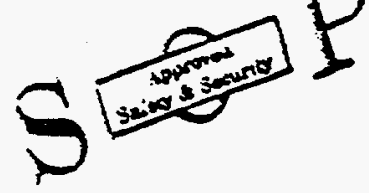




\section{Appendix C}

\section{Intermediate-Scale High Solids Anaerobic Digester \\ Internal Bearing Change out Procedure}

The following procedures are to be followed during removal and change out of the internal bearing in the intermediate-scale high solids anaerobic digester in order to reduce the risk of personnel exposure to biogas. These procedures are instituted in addition to the warm room ventilation system controls already in place and which serve to sweep the atmosphere from the warm room using the building exhaust system.

The following steps must be performed in the sequence specified in order to achieve the maximum level of safety during bearing change out operation.

1. Prior to attempting any operation in which the intermediate-scale digester is opened, both the secondary exhaust fans and the high bay purge fans (dump fans) must be engaged to ensure the maximum level of building exhaust. Additionally, the hydraulic power to the digester mixing system (agitator) must be disengaged and locked out at the electrical timer box (located within the gray hydraulics cabinet outside of the warm room).

2. A tank of UHP nitrogen with appropriate regulator should be located adjacent to the ship ladder on the outside of the warm room. The tank must be suitably secured and the regulator attached to the digester exhaust line using reinforced tygon tubing. With both 3 -inch ball valves on the digester open, the red rubber end cap on the feed port is removed (this cap is at the top of the 3-inch feed port tube). Initially overpressure in the digester is released, the volume of biogas is approximately 20 - 30 liters total. The digester is now flushed with nitrogen by opening the tank regulator for 30 minutes to remove biogas from the head space of the digester.

3. After 30 minutes of flushing with nitrogen, the nitrogen purge is discontinued and the endplate is removed. The bearing assembly is removed using appropriate tools and transferred outside of the warm room to the sink for cleaning, disassembly, and reassembly.

4. Immediately following removal of the bearing assembly, a plexiglass endplate is attached to the open end of the reactor using $4 \mathrm{C}$-clamps to reduce exposure of the warm room air to the contents of the digester. At this time the nitrogen purge is initiated to continuously remove biogas produced by the active sludge. With the plexiglass endplate in place, the nitrogen purge is conducted out of the top of the 3-inch feed tube.

5. Prior to reinstalling the internal bearing assembly, the nitrogen purge is discontinued and the plexiglass endplate is removed. Following bearing installation, the endplate is installed, the red rubber end cap is connected to the top of the feed tube, and the nitrogen purge is removed and the gas tubing reattached to the gas monitoring system.

6. Finally, the hydraulic power to the digester mixing system is engaged and the high bay secondary and purge fans are turned off. At this point the digester system is ready for nomal operation. 


\section{Fafnir \\ Corrosion-Resistant Ball Bearing Housed Units}

Unique, corrosion-resistant housed units provide premium bearing performance and reliable protection in harsh environments.

SURVIVOR ${ }^{\text {TM }}$ ball bearing housed units are specifically designed to offer optimum corrosion resistance for food processing and other demanding applications. The combination of outstanding bearing and housing features creates an unmatched performance package that withstands a wide range of common corrosives and contaminants.

The SURVIVOR series is the industry's first housed unit to incorporate a completely corrosion-resistant bearing insert. Outstanding protection is provided by the FAFNIR TDC ${ }^{\text {TM }}$ ball bearing insert and the electrolessnickel-plated housing.

The proprietary thin, dense-chrome bearing coating uses proven technology to set new industry standards. All other bearing components are stainless steel, synthetic rubber or nylon. In addition, the bearings are prelubricated with a food-grade grease. The result is a high-pertormance bearing package that is unique in the industry.

\section{SURVIVOR Unit Benefits}

- Reliable Protection - unique combination of corrosion-resistant bearing insert and housing provides best protection package available.

- Superior Bearing Insert - FAFNIR TDC ${ }^{\mathrm{M}}$ thin, dense-chrome coating will not crack or peel under known application conditions, providing proven bearing corrosion resistance. Full width bearing provides greater grease storage and shaft support than narrow designs.

- Longer Life - TDC coating resists premature failure under corrosive conditions.

- Plated Housing - electrolessnickel-plated housing, with stainless steel grease fitting and protective cap, withstands corrosion and prevents contamination.
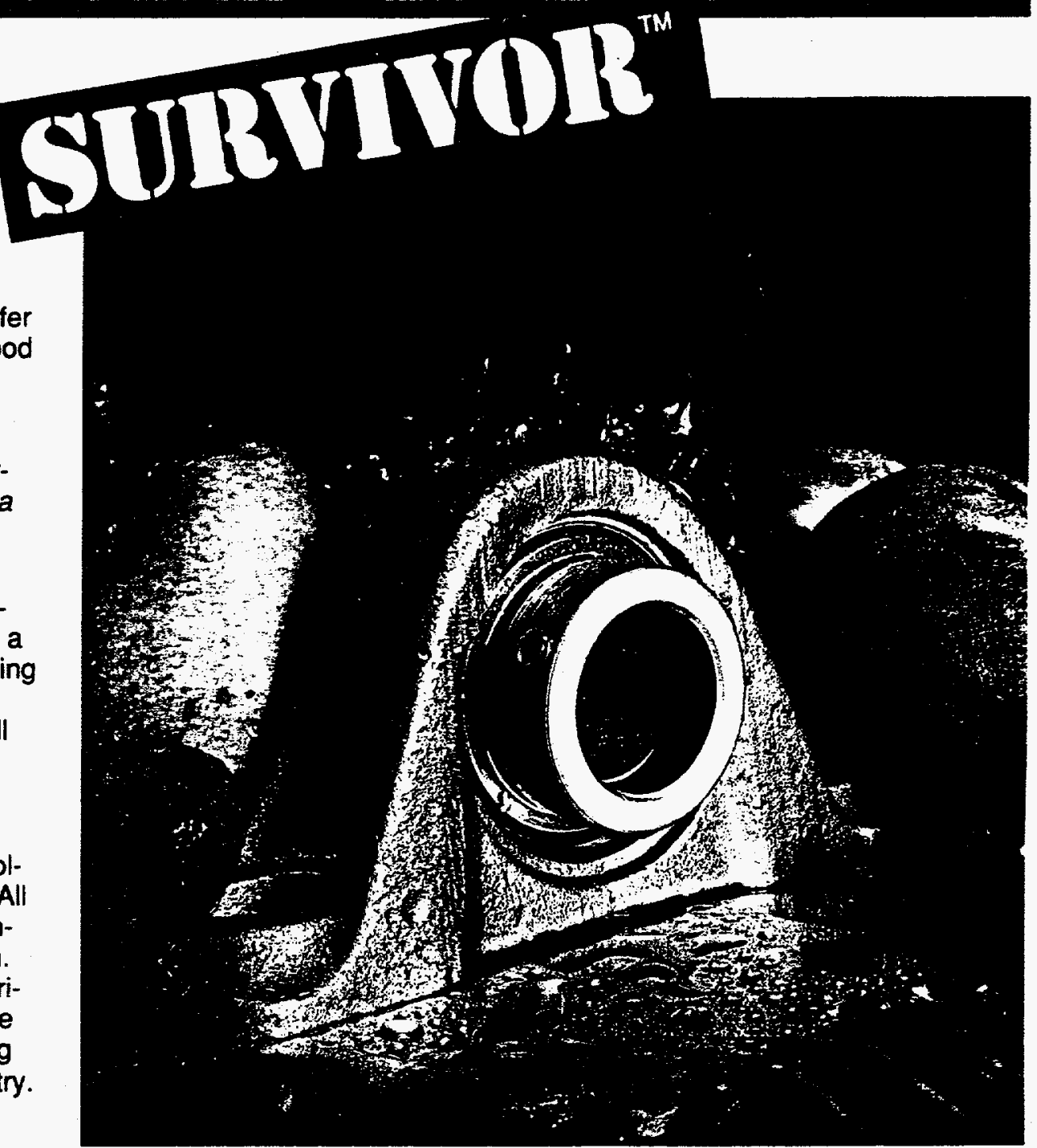

SURVIVOR housed units offer an outstanding package of features for optimum corrosion resistance in harsh operating environments.

- Total Value Package - a single unit with the best components available provides valuable reliability in difficult applications.

- Proven Performance - SURVIVOR units outperformed other designs in severe 100-hour salt spray tests (ASTM-B-117).

- Government Requirements - all materials, including lubricant, comply with all applicable FDA and USDA requirements.

- Mounting Variations - available as RAK/RAS pillow blocks, RCJ/ RCJT flanged units in two and fourbolt configurations, and RTU take-up units.

\section{Applications}

- Food Processing Plants

- Beverage Plants

- Dairy Industries

- Refrigeration Plants

- Food Packaging

- Harvesting Equipment

- Chemical \& Rubber Processing

- Pharmaceutical Industries

- Paper Mills

- Highway Salt \& Sand Trucks

- Car Washes

- Material Handling

- Maritime Applications 


\section{Applications}

\section{Unit Design}

Shroud Seals

Synthetic Rubber Stainless Steel Caps

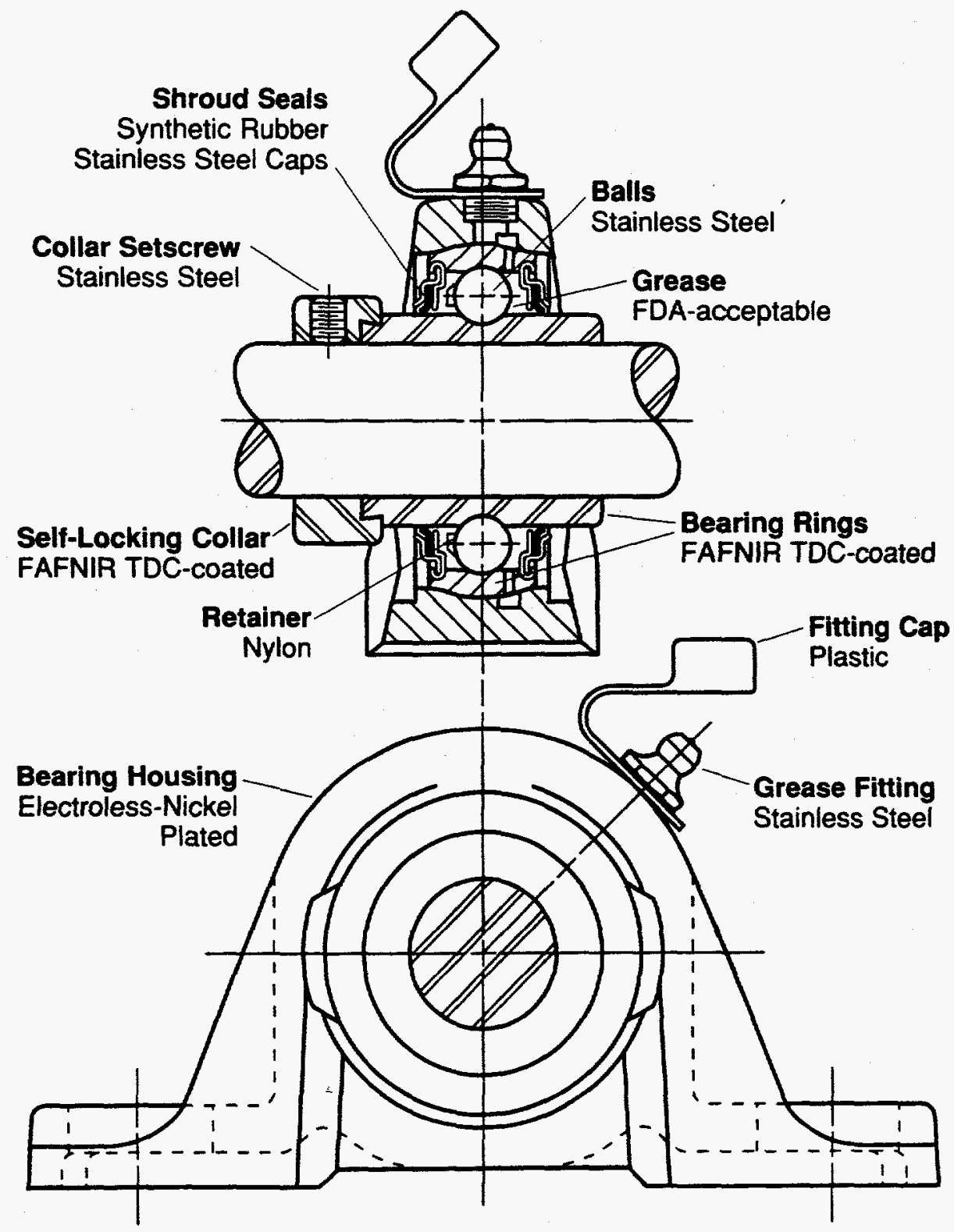

Self-Locking Collar FAFNIR TDC-coated

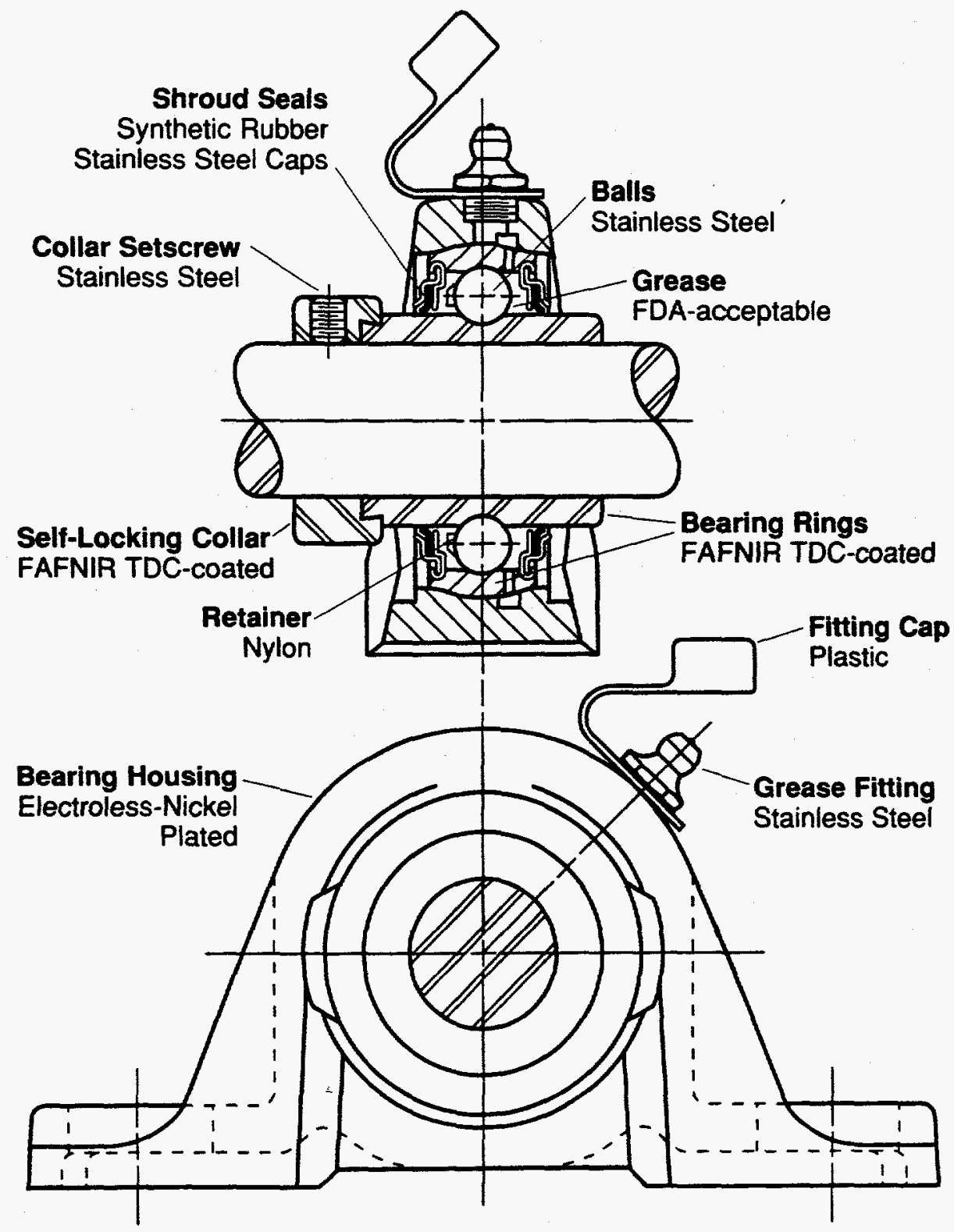

Originally developed to meet strict government standards and other food processing requirements, SURVIVOR ${ }^{\mathrm{M}}$ housed units are a dependable solution for applications where resistance to corrosion and contamination is critical. SURVIVOR units can solve difficult bearing problems from the food and beverage industries to paper mills, material handling and maritime installations.

SURVIVOR units are specifically designed to provide reliable performance in the harshest environments. The combination of features creates a superior assembly that offers outstanding corrosion protection and dependability. The FAFNIR TDC coating will not crack or peel under known application conditions, providing proven reliability in harsh environments.

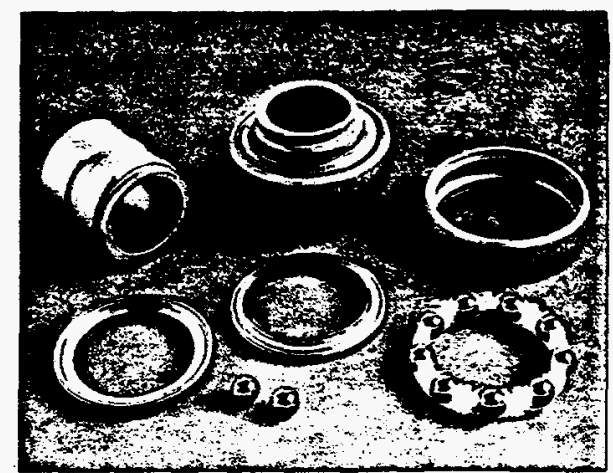

All bearing components have been carefully selected for their corrosion-resistant properties.

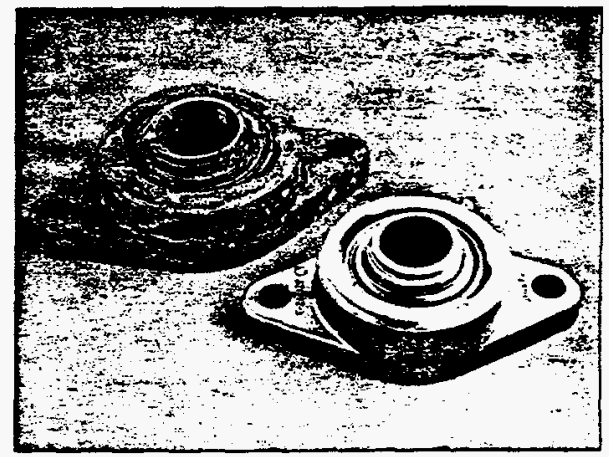

The SURVIVOR unit outperformed other designs in demanding salt spray tests.

\section{Ordering Information}

SURVIVOR housed units are available in a range of popular shaft sizes from 1/2 in. to 2-3/16 in. Check for current availability.

To order a SURVIVOR unit, simply add the suffix "NT" after the standard bearing designation, i.e., RAK 1-7/16-NT. Orders may be placed through any of The Torrington Company's district offices or authorized distributor branches throughout North America. For the location and number of the closest office, please call (800) 243-8160.

Fafnir Bearings Division

The Torrington Company 59 Field Street Torrington, CT 06790 (203)482-9511

\section{TORRINGTON}

Part of worldwide Ingersoll-Rand

(c) 1990 The Torrington Co.

Printed in U.S.A. Form No. 628-100M-890 
DODGE ${ }^{\circ}$ E-Z KLEEN ${ }^{\circ}-\quad$ Appenentix 6. Sleeve Bearing with Pölymer Insert Easy washdown after splashdown.

With the new sleeve bearing you get all the features of the

DODGE E-Z KLEEN bearing with housings coated with Tollorr

- plus the added chemical and corrosion resistam polymer sleeve

(PS) insert. The polymer sleeve is self-lubricated for a

maintenance-free environment.

- Corrosion and Abrasion Resistant

- Polymer Sleeve Resists Fungus and Bacteria Growth

- Quiet Operating Characteristics-Excellent Sound

Dampening

- Subzero Ambient Temperatures Down to $-40^{\circ} \mathrm{F}$

- Can Operate in Wet Environments

- Conforms to FDAUUSDA Specifications

- Self-Lubricating Polymer Sleeve Inser

- Low Coefticient of Friction

- Wide Variety of Housing Configurations

- Available in All Popular Bearing Bore Sizes

- Anti-Rotation Device Prevents Rotation of the Polymer Insert within the Housing

'Registered trademark of DuPont Co.
Insorts - The domestically manuiactured DODGE Standard E-Z KLEEN PS Bearing is installed in a housing that is coated with Teflon to produce a dependable rugged mounted unit. The Polymer Sleeve Inserts are designed to take the constant washdowns the food. chemical and processing industries require and coniorm to FDAUSDA specifications for tood contact.

Anth-fotation-An anti-rotation device prevents the inserts from rotating in the housing under unbalanced load conditions. Housings-The one-piece gray iron housing is specially machined to accommodate Teflon coating. The thickness of the coating is $.003 \pm .001$ and is designed to resist abrasion. chipping and flaking in acidic or caustic environments. The
Teflon coating conforms to FDAUSDA specitications for food contact.

Lubrication-No lubrication is required on E-Z KLEEN Sleeve Bearings.

DODGE E-Z KLEEN Bearings with housings coated with Tefion are suitable for meat processing and packing, dairy products. bottling, canning, vegetable and truit processing, bakery and confection, cereal, seafood processing, frozen toods, and pharmaceutical and cosmetic industries.

E.Z KLEEN Bearings with housings coated with Teflon are available in standard height pillow blocks, 4-bolt and 2-bolt flanges.

U.S Patents $4973172,5028151,5074040$ and 5107589

\section{Dimensions:*}
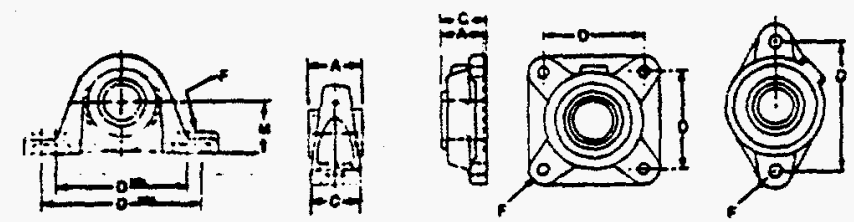

\begin{tabular}{|c|c|c|c|c|c|c|c|c|c|c|c|}
\hline \multirow{3}{*}{$\begin{array}{l}\text { Shaft } \\
\text { Sires }\end{array}$} & \multirow[b]{3}{*}{ Ring Size } & \multirow{3}{*}{$\mathbf{A}$} & \multicolumn{2}{|c|}{ C } & \multicolumn{4}{|c|}{0} & \multirow{2}{*}{\multicolumn{2}{|c|}{$\begin{array}{c}F \\
\text { Boft Dia. }\end{array}$}} & \multirow{3}{*}{$\begin{array}{c}\text { M } \\
\text { Pillow } \\
\text { Block }\end{array}$} \\
\hline & & & \multirow[b]{2}{*}{ PQ } & \multirow[b]{2}{*}{ Fo. } & \multicolumn{2}{|c|}{ Pillow Blocks } & \multirow{2}{*}{$\begin{array}{l}\text { 4-Bot } \\
\text { Flange }\end{array}$} & \multirow{2}{*}{$\begin{array}{l}\text { 2-Boll } \\
\text { Flange }\end{array}$} & & & \\
\hline & & & & & Min. & Max. & & & P.B. & Fig. & \\
\hline $3 / 4$ & 204 & 1 & $111 / 32$ & $1 \%$ & $33 / 6$ & $43 / 16$ & $21 / 2$ & $3^{17 / 32}$ & $3 / 6$ & $3 / 6$ & $15 / 4$ \\
\hline 1 & 205 & $71 / 10$ & $193 / 32$ & $1 \%$ & $3^{11 / 10}$ & $41 / 2$ & $2^{3 / 4}$ & $3^{57 / 64}$ & $3 / 6$ & $7 / 16$ & $17 / 16$ \\
\hline $\begin{array}{l}19 / 10 \\
11 / 4\end{array}$ & 206 & $13 / 16$ & $13 / 4$ & $17 / 32$ & $41 / 4$ & 5 & $3 \%$ & $410 / 52$ & $1 / 2$ & $7 / n$ & $15 / 0$ \\
\hline $11 / 4$ & 207 & $13 / 16$ & $13 / 4$ & $1 \%$ & $411 / 16$ & $57 / 10$ & $35 / 0$ & $5 \%$ & $1 / 2$ & $1 / 2$ & $17 / 6$ \\
\hline $11 / 2$ & 208 & $10 / 16$ & 2 & $1^{11 / 32}$ & $5^{3 / 16}$ & $57 / 8$ & 4 & $5^{21 / 32}$ & $1 / 2$ & $1 / 2$ & $21 / 6$ \\
\hline $185 / 16$ & 210 & $15 / 4$ & $21 / 4$ & $121 / 32$ & 6 & $6^{11 / 10}$ & $43 / 6$ & $63 / 18$ & $5 \%$ & $1 / 2$ & $21 / 4$ \\
\hline
\end{tabular}

\begin{tabular}{|c|c|c|c|c|c|c|c|c|c|c|c|c|c|c|}
\hline \multirow[b]{2}{*}{$\begin{array}{l}\text { Ring } \\
\text { Size }\end{array}$} & \multirow[b]{2}{*}{$\begin{array}{l}\text { Shaft } \\
\text { Size }\end{array}$} & \multicolumn{13}{|c|}{ - Padial Load Ratings (Lbs.) al Various Revolutions per Minute } \\
\hline & & $\begin{array}{c}\text { Up to } \\
10\end{array}$ & 25 & 50 & 75 & 100 & 150 & 200 & 250 & 300 & 350 & 400 & 450 & 500 \\
\hline $\begin{array}{l}204 \\
205 \\
206\end{array}$ & $\begin{array}{c}3 / 4 \\
1 \\
13 / 16.11 / 4\end{array}$ & $\begin{array}{l}375 \\
530 \\
700\end{array}$ & $\begin{array}{l}375 \\
530 \\
700\end{array}$ & $\begin{array}{l}375 \\
530 \\
700\end{array}$ & $\begin{array}{l}375 \\
530 \\
550\end{array}$ & $\begin{array}{l}375 \\
350 \\
350\end{array}$ & $\begin{array}{l}200 \\
175 \\
175\end{array}$ & $\begin{array}{l}110 \\
110 \\
110\end{array}$ & $\begin{array}{l}75 \\
75 \\
75\end{array}$ & $\begin{array}{l}55 \\
55 \\
55\end{array}$ & $\begin{array}{l}45 \\
45 \\
45\end{array}$ & $\begin{array}{l}35 \\
35 \\
35\end{array}$ & $\begin{array}{l}30 \\
30 \\
30\end{array}$ & $\begin{array}{l}25 \\
25 \\
25\end{array}$ \\
\hline $\begin{array}{l}207 \\
208 \\
210\end{array}$ & $\begin{array}{c}11 / 4,17 / 10 \\
11 / 2 \\
115 / 10\end{array}$ & $\begin{array}{r}820 \\
1125 \\
1575\end{array}$ & $\begin{array}{r}820 \\
1125 \\
1575\end{array}$ & $\begin{array}{r}820 \\
1125 \\
1125\end{array}$ & $\begin{array}{l}600 \\
550 \\
500\end{array}$ & $\begin{array}{l}350 \\
350 \\
325\end{array}$ & $\begin{array}{l}175 \\
175 \\
175\end{array}$ & $\begin{array}{l}110 \\
110 \\
110\end{array}$ & $\begin{array}{l}75 \\
75 \\
75 \\
\end{array}$ & $\begin{array}{l}\mathbf{5 5} \\
\mathbf{5 5} \\
\mathbf{5 5}\end{array}$ & $\begin{array}{l}45 \\
45 \\
45\end{array}$ & $\begin{array}{l}35 \\
35 \\
35\end{array}$ & $\begin{array}{l}30 \\
30 \\
30\end{array}$ & $\begin{array}{l}25 \\
25 \\
25\end{array}$ \\
\hline
\end{tabular}

Operating Temperature Range: $-40^{\circ}$ to $100^{\circ} \mathrm{F}$.

For loads and speed combinations not shown on this chart or thust load capabilities contact DODGE Engineering, Columbus, IN.

Due to unknown loads on take-ups, E-Z KLEEN sleeve bearings are not recommended for use as a take-up bearing.

Commercial shatting tolerance is acceptable, however, a tinish of 10-20RA will reduce bearing wear.

DOOGE collars are available and should be purchased separately for shaft location.

Padial load ratings were established for normal operating condrions, the service life may be rectuced due to harsh environmental conditions with excessive temperature. dit and abrasive materials. Therelore. fietd testing is recommended to verity bearing operating pertormance under harsh emironmental conditions. 
Appendix 7a.

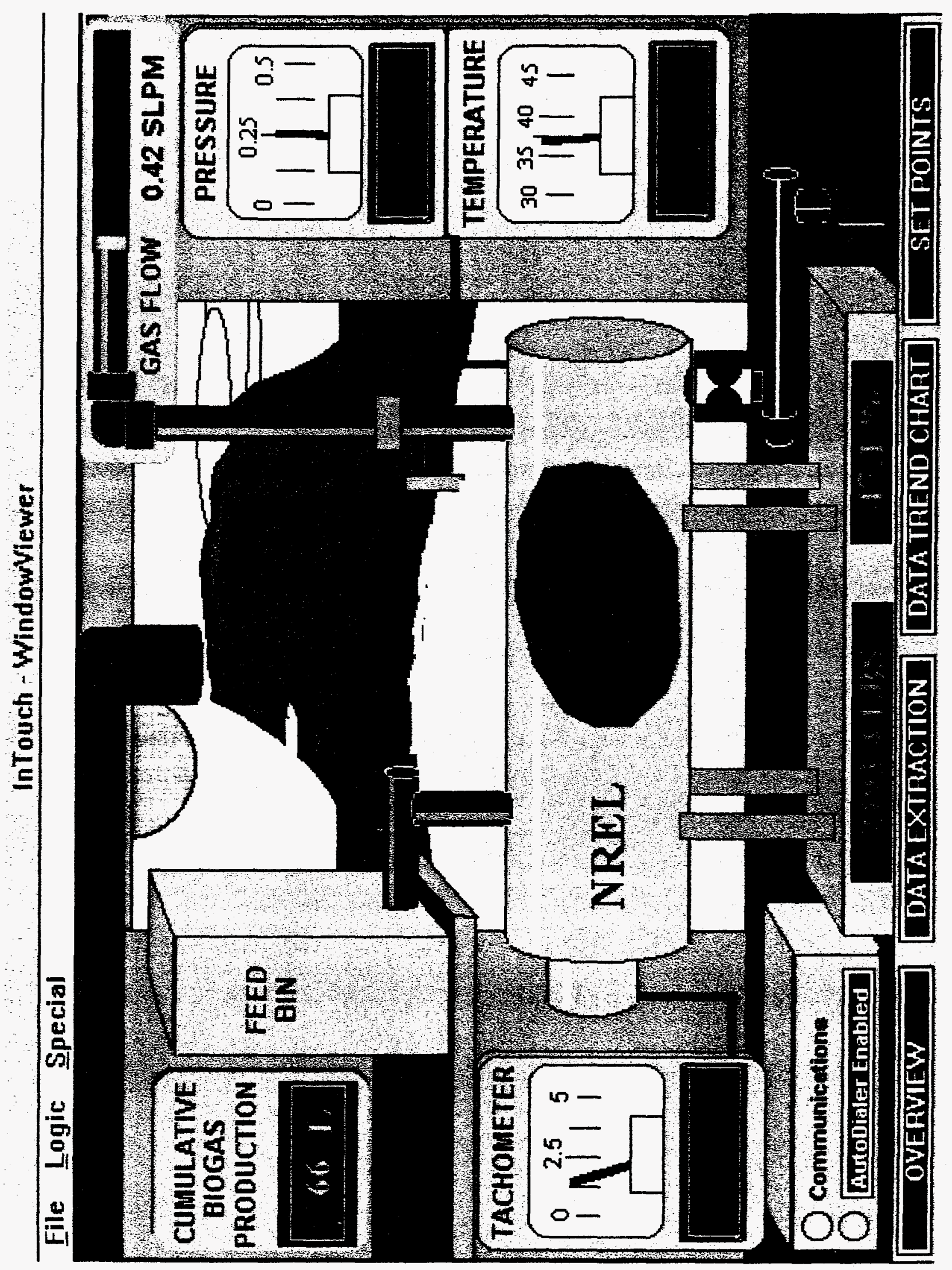


Appendix $7 b$.

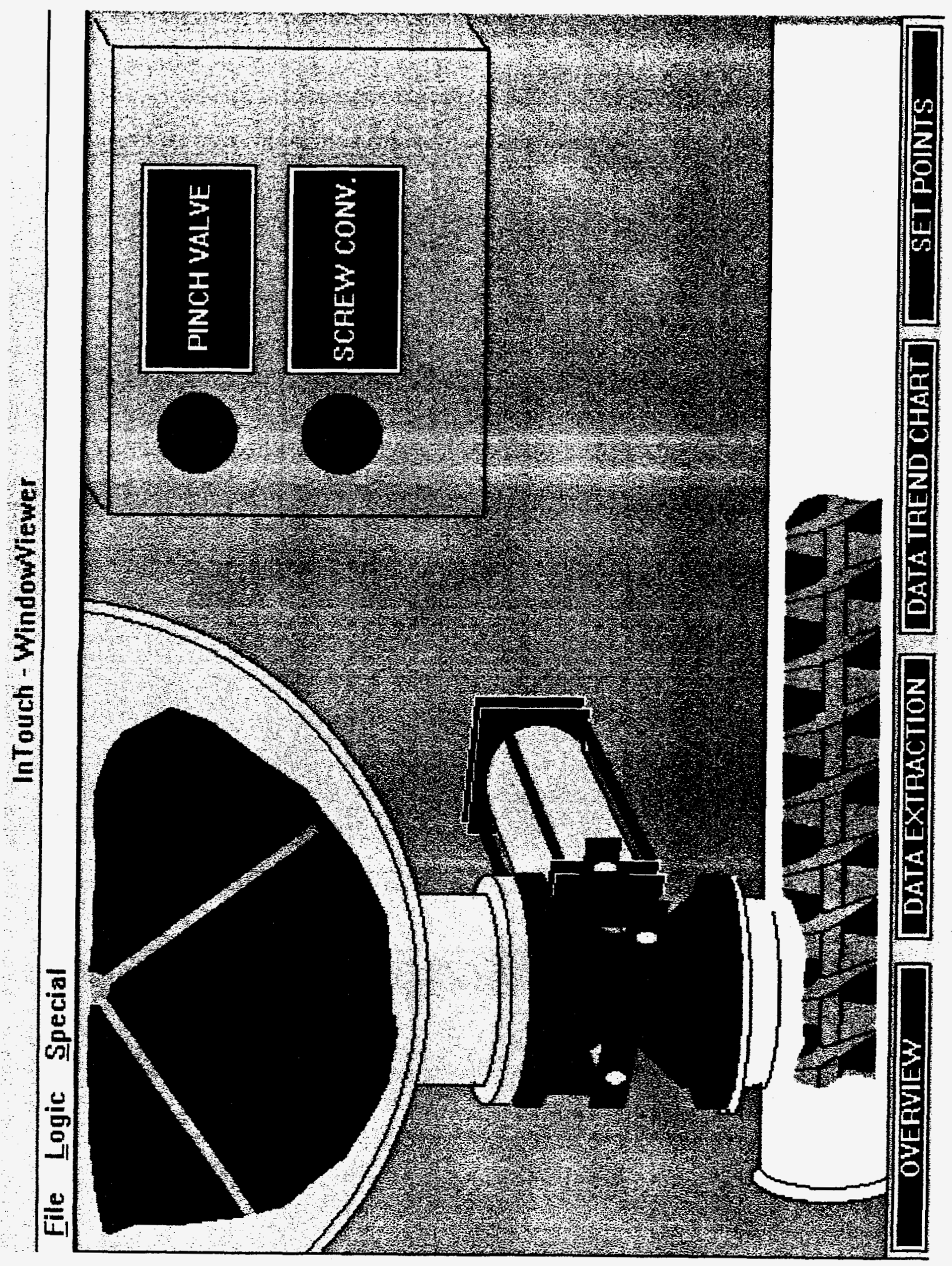




\begin{tabular}{|c|c|c|c|}
\hline & & $\%$ & uoparenuos \% \\
\hline & & $\%$ & t10\% \\
\hline & & sอนา & sejoul 2 \\
\hline & & 8อบ7 & sapou + 1 \\
\hline & & $\%$ & S1\% \\
\hline & SEJON & & Hd \\
\hline$=0$ & $=0 \mid$ & $=\varnothing$ & $(n w) s, y=n$ \\
\hline & & 'sql $9.12 k 2$ & 4\%9M \\
\hline Nid 6.1 & ndy & Hod LI & poods \\
\hline Mdn $0^{\circ} s$ & ind $0^{\circ} 0$ & Hd $2 !$ & MOSH \\
\hline $18 \cdot d \quad r 0$ & 1.80 & is.d & anssald \\
\hline 20 tor & 28.98 & Oo $+8 \varepsilon$ & ampiedure 1 \\
\hline unuppew & unwu!ulw & ebejony & \\
\hline
\end{tabular}

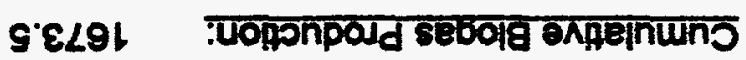
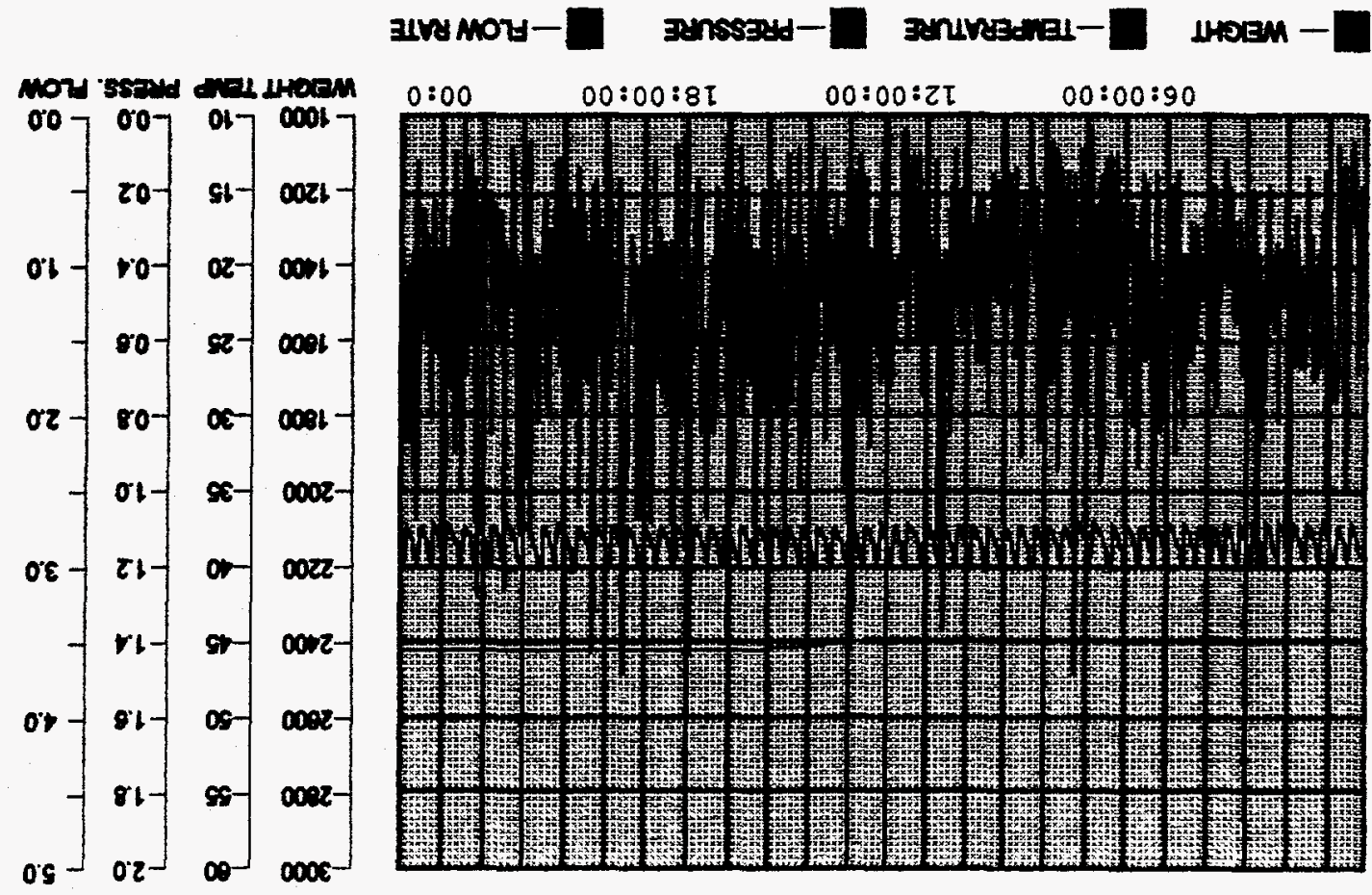

$\$ 6 / T / L$ 
Table 1. Feedstock Characteristics

\begin{tabular}{lcc} 
Parameter & \multicolumn{2}{c}{ Feedstock } \\
\cline { 2 - 3 } & MSW (RDF) & Tuna Sludge \\
\hline \hline Total Solids (\%) & $96.8 \pm 0.2$ & $24.9 \pm 1.6$ \\
Volatile Solids (as \% of TS) & $88.8 \pm 0.5$ & $94.2 \pm 0.9$ \\
Ash (as \% of TS) & $11.2 \pm 0.5$ & $5.8 \pm 0.9$ \\
Chemical Oxygen Demand (g COD/g wet wt) & $1.21 \pm 0.11$ & $0.35 \pm 0.03$ \\
pH & $\ldots$ & 5.3 \\
Volatile Fatty Acids (C2-C5, mM) & $\ldots$ & $117.9 \pm 14.2$ \\
Free Ammonia (g/L) & $\ldots$ & $0.78 \pm 0.08$ \\
\hline \hline
\end{tabular}

Table 2. Intermediate-Scale High Solids Digester Performance at Various OLRs

\begin{tabular}{|c|c|c|c|c|c|c|c|c|}
\hline Organic Loading Rate $(\mathrm{gVS} / \mathrm{L} \cdot \mathrm{d})$ & 4 & 8 & 10 & 12 & 14 & 16 & 18 & 20 \\
\hline Biogas Production $(L / L \cdot d)$ & $3.19 \pm 0.31$ & $5.62 \pm 0.52$ & $8.10 \pm 0.52$ & $9.88 \pm 0.90$ & $10.51 \pm 1.10$ & $11.50 \pm 1.09$ & $12.61 \pm 0.99$ & $12.94 \pm 1.46$ \\
\hline Methane Content (\%) & $57.7 \pm 3.4$ & $63.4 \pm 3.1$ & $57.5 \pm 1.2$ & $56.0 \pm 1.4$ & $58.8 \pm 1.7$ & $60.1 \pm 2.0$ & $59.7 \pm 2.3$ & $59.1 \pm 2.8$ \\
\hline Methane Production $(\mathrm{L} / \cdot d \mathrm{~d})$ & $1.84 \pm 0.18$ & $3.56 \pm 0.33$ & $4.66 \pm 0.36$ & $5.53 \pm 0.50$ & $6.18 \pm 0.69$ & $6.91 \pm 0.81$ & $7.53 \pm 0.88$ & $7.65 \pm 1.10$ \\
\hline COD Loading (g COD/L•d) & 5.9 & 11.7 & 14.6 & 17.5 & 20.4 & 23.3 & 26.2 & 29.2 \\
\hline \% Bioconversion* & $85.5 \pm 8.5$ & $83.9 \pm 7.7$ & $87.7 \pm 6.7$ & $86.8 \pm 7.9$ & $83.1 \pm 7.2$ & $81.2 \pm 8.1$ & $78.6 \pm 6.9$ & $71.4 \pm 9.1$ \\
\hline Sludge Total Solids (\%) & $26.3 \pm 1.3$ & $26.7 \pm 1.8$ & $26.2 \pm 2.1$ & $26.5 \pm 1.9$ & $26.8 \pm 3.2$ & $27.2 \pm 2.9$ & $27.8 \pm 3.1$ & $28.2 \pm 4.1$ \\
\hline Sludge pH & $7.4 \pm 1.1$ & $7.4 \pm 1.8$ & $7.3 \pm 1.6$ & $7.3 \pm 1.1$ & $7.3 \pm 1.8$ & $7.3 \pm 1.4$ & $7.2 \pm 2.1$ & $7.2 \pm 1.9$ \\
\hline Sludge VFAs (C2-5, mM) & 23.1 & 32.1 & 29.1 & 39.1 & 44.4 & 59.7 & 54.7 & 59.2 \\
\hline Sludge Ammonia (g/L) & 1.3 & 1.3 & 1.3 & 1.2 & 1.3 & 1.3 & 1.3 & 1.2 \\
\hline
\end{tabular}

* The percent anaerobic bioconversion was determined from the COD loading to the process using the relationship of 1 gram of COD is equivalent to $0.35 \mathrm{~L}$ of methane. All methane production values were first corrected for STP prior to calculating the percent bioconversion. 